\title{
LEON TROTSKY'S ADVENTURE IN AMERICAN RADICAL POLITICS. $1935^{-1} 7^{1}$ )
}

On 24 January 1936 Rose Karsner of New York City received a cablegram from Norway: "PERSONALLY IN FAVOUR OF ENTRY-LEO." The sender of the cablegram was the exiled Bolshevik leader, Leon Trotsky, and the recipient was the wife of the most important "Trotskyist" leader in the United States, James Cannon. ${ }^{2}$ The Russian revolutionary thus gave his blessing to a new manoeuvre by which the American Trotskyists were to enter the Socialist Party of America for certain well-defined objectives.

The purpose of this paper is to describe the story of a political adventure in the United States largely masterminded by Trotsky. Till the publication recently of the third and final volume of Isaac Deutscher's biography of the "Prophet", very little had been written concerning the activities of Trotsky following his expulsion from the Soviet Union. ${ }^{3}$ Trotsky's own "diary in exile" published in 1958 by

1 Dr. Venkataramani is Head of the Department of American History and Institutions, Indian School of International Studies, New Delhi.

2 "Leo" (Trotsky) to Rose Karsner, 24 January I 936, James P. Cannon Papers. The Papers are in the personal custody of Mr. Cannon and the writer examined them in Mr. Cannon's residence in Los Angeles, California. Letters from Leon Trotsky cited in this article were mostly in German and occasionally in French. Exact English translations of the letters were made by trusted American friends for Mr. Cannon who was not acquainted with those European languages. Trotsky used various pseudonyms in his letters to his American followers.

Cannon is one of the interesting figures in Ametican radical annals. Born in Kansas in 189o, he got his early training in agitation, propaganda and organization in the Socialist Party and the militant Industrial Workers of the World (IWW). A founding member of the Communist Party (USA) Cannon was expelled in 1928 for his open support for Trotsky's ideological views. Along with a few comrades he founded the American Trotskyist movement of which he remains the most outstanding and articulate spokesman even at the present day.

s Isaac Deutscher, The Prophet Outcast (London, 1963). This important work reached the present writer's hands in India when this paper had been completed. 
Harvard University Press stops abruptly with the entry for 8 September I $935 .{ }^{1}$ Why? What were the problems confronted at that time by the restless Bolshevik? What connection did they have with his advice to his American followers to enter the Socialist Party (SP) of the United States? How were his instructions executed? What was the effect on the SP, a democratic political party with lax discipline, of the infiltration of a disciplined group of persons whose political ethics were those of the Bolshevik professional revolutionist and who were guided by no less a person than the comrade-in-arms of Vladimir Lenin?

\section{TROTSKY'S TRAVAILS IN I935}

In 1935 Trotsky was living in uneasy exile in France. Though he was out of the clutches of his ruthless antagonist, Josef Stalin, Trotsky had a strong premonition of impending calamity. For the first time in his life he began keeping a diary. The arrest of Leon Kamenev and Gregory Zinoview, the horrid accusations hurled against them by Stalin, and the unanimity with which the charges were echoed by the Communist parties of other nations came as a shock to Trotsky. ${ }^{2}$ Gloomily he recalled that nine years earlier the two arrested leaders had warned him that Stalin was determined to encompass Trotsky's moral and, if possible, physical destruction. Stalin would plan, they said, to "slander you, to trump up a military conspiracy, and then when the ground has been prepared, to perpetrate a terroristic act." "Lies, falsification, forgery, and judicial perversion have assumed [in Stalin's Russia] a scale hitherto unheard of in history", Trotsky wrote in his diary as he followed the ordeal of Kamenev and Zinoviev in Moscow. ${ }^{3}$ Was their arrest a curtain-raiser to new and diabolical plans against himself?

Trotsky's forebodings were confirmed when early in April he heard that his first wife had been deported to Siberia and that the husband of his deceased daughter had been arrested. For a disturbingly long time there had been no letters from his son, Seryozha, a professor in a Soviet technological institute. Pravda had reported that "Trotskyists and Zinovievists" were among over a thousand "anti-Party elements and enemies acting under the direction of foreign intelligence services" who had been deported to Siberia. "The knifeblade of "political action' is once again pointed toward people personally close to me",

${ }^{1}$ Leon Trotsky, Trotsky's Diary in Exile 1935 (Cambridge, Mass., 1958). The publisher's foreword to this work refers specifically to the paucity of information concerning Trotsky's life after his banishment from the Soviet Union in 1929.

2 Diary entry, I4 February 1935; ibid., pp. 16, 20.

${ }^{3}$ Diary entries, I 8 February I935, 7 March I935; ibid., pp. 23, 35. 
Trotsky recorded in his diary. His fears proved to be too true and the exiled Communist and his wife, Natasha, were plunged in terrible grief when they received a letter from Seryozha informing them that he had been imprisoned several months earlier. ${ }^{1}$

Trotsky knew that his adherents outside the Soviet Union were a mere handful. He knew also that the Communists, following the lead of Moscow, would leave no stone unturned to isolate his followers and, by their vociferous propaganda, drown any protest against Stalin's accusations. Trotsky also knew that his stay in France itself was precarious and that he might be forced out of the country at any time. It was in order to strengthen his position against all these problems and contingencies that, in the opinion of this writer, Trotsky must have made his decision to instruct his followers to join the Socialist Party of France - a manoeuvre that came to be known as "the French turn". But the tactic did not work out satisfactorily because of the ineptitude of his French adherents and because of the unrelenting campaign of the Comintern. Impressed by the danger posed by Nazi Germany, French Socialists were in favour of an accord between their country and the USSR and were in no mood to harbour in their midst the proclaimed enemies of the Russian dictator.

When early in May i 935 the Franco-Soviet Pact was signed, Trotsky concluded that his days in France were numbered and made anxious preparations to find sanctuary in Norway where a social democratic government was in power. Towards the end of July, about a month after his arrival in Norway, Trotsky learned that his followers had been expelled from the French Socialist Party. No other "official" labour or socialist party in Europe evinced any readiness to provide a haven to Trotsky or his followers.

TROTSKY'S QUEST FOR AN INTERNATIONAL INQUIRY COMMISSION

Trotsky thus stood alone, acutely conscious of the long arm of Stalin reaching for him. His wife grieved for her imprisoned son; Trotsky shared her grief but he seemed to be far more concerned over the question of vindicating himself against Stalin's charges. Trotsky would have been appalled at any suggestion that he was at all interested in a personal vindication. He apparently believed with profound sincerity that it was not Trotsky, the man, who stood in need of vindication but the cause of the proletarian world revolution which had been betrayed and slandered by the Thermidorian from Georgia. Such vindication could come only out of an independent ${ }_{1}$ Diary entries, 2 April I935, 3 April 1935, 4 April 1935, I June I935; ibid., pp. 58-60, $60-62,64,129$. 
investigation of the charges by a tribunal of internationally respected personalities, Trotsky reasoned. A letter drafted by his wife, but with many changes and interpolations by Trotsky, appealed to labour organizations and foreign friends of the USSR to sponsor an open enquiry into the charges by "an international commision of authoritative and conscientious people, known, needless to say, to be friends of the USSR ...Couldn't Romain Rolland, Charles [sic] Gide, Bernard Shaw and other friends of the Soviet Union take the initiative to create such a Commission by agreement with the Soviet Union? This would be the best method for investigating the truth of the accusations and suspicions which are widespread among the working masses."1

The lack of response to this appeal might have convinced Trotsky of the hopelessness of expecting any succour from European organizations or leaders. What then was the way out? Perhaps Trotsky concluded that there could be some hope that his case would not be completely smothered if he could enlist the support of the liberals of the United States of America. The tiny Trotskyist group in the United States had no standing among American liberals. But the Socialist Party of America had a good name among the country's liberals and its principal leader, Norman Thomas, was not only highly respected but was exceedingly active in the field of civil liberties. If the American Trotskyists could get into the Socialist Party, there was a chance that Stalin's attempts to grind him into the dust would meet with a ringing protest from American liberals - a protest that might have world-wide impact.

\section{THE SOCIALIST PARTY'S PROBLEMS I 935-6}

The Socialist Party of America, the party of Eugene ("Gene") Debs and Morris Hillquit, was at that time in the throes of a serious internal crisis. Factionalism had been mounting in the Party ever since a controversial Declaration of Principles was adopted at the national convention held in Detroit in 1934. Veteran Socialists (the Old Guard), especially in New York, regarded the Declaration as a dangerous and incendiary document and castigated its sponsors as pushing the Party in the direction of communism and armed insurrection. Supporters of the Declaration were Socialists who styled themselves as "Militants" and who wanted to give a revolutionary turn to the Party's programme and activities. As the factional struggle continued it became clear that each side was anxious to bring the matter to a head and to decide once for all who should control the

1 Text of the letter, ibid., pp. $129-33$. 
apparatus and thereby the policies of the Socialist Party of America. The internal conflict was of great interest to the Communist Party which, in line with the Comintern policy of the time, was anxious to forge a Popular Front with the Socialist Party. The Communists were even prepared to discuss the question of organic unity; if that was not possible, they were willing to accept a joint Socialist-Communist ticket in the 1936 presidential election. ${ }^{1}$

American Trotskyists were also watching these developments with earnest attention. They were not able to effect a "French turn" because the Old Guard of the Socialist Party was bitterly hostile to the entry of communists of any breed into their organization. The Trotskyists led by James Cannon and Max Shachtman then fused into the American Workers Party, a small, militant, noncommunist group led by A. J. Muste, but they continued their careful study of developments inside the Socialist Party ${ }^{2}$. Especially anxious were the Trotskyist leaders to forestall any attempt by the Communists to infiltrate into the Socialist Party and to establish close contacts with the Militants. Thus, while both the Communist and Trotskyist organs cheered the Militants in their fight against the Old Guard, they also kept a watchful and hostile eye on each other's moves.

The Communist Party's chances were, however, quite dim; their interest also became progressively less as they moved audaciously after bigger game. Most Socialists, including the Militants, could not forget the abuse that had been heaped upon them by the Communists in the past. The Trotskyists, on the other hand, had been the victims of similar abuse. They had covered their identity by appearing in the clothes of the Workers Party. In strikes and other mass activities they had been coming into contact with Socialist activists. To the latter the Trotskyists appeared to be seasoned and dedicated workers. In revolutionary phrase-making, the Communists appeared tame in comparison with the Trotskyist "theoreticians". Above all, the Trotskyists seemed to be not only unafraid of the Communists but also always most anxious and ready to challenge them frontally. Their faith and discipline were in contrast to the free and easy ways of

1 For an account of these developments, see M. S. Venkataramani, "United Front Tactics of the Communist Party (USA) and Their Impact on the Socialist Party of America, I932-6", in: International Studies (New Delhi), I (October, 1959), pp. 154-83.

2 Shachtman was the principal lieutenant of Cannon during the period under review. Highly intelligent and articulate, Shachtman was the general editor of the English edition of Trotsky's works. Cannon and Shachtman fell apart subsequently and the latter, after outgrowing the Bolshevism of his earlier years, has recently returned to the Socialist Party - Social Democratic Federation of the United States. A. J. Muste, a dedicated pacifist and Christian Socialist, is still active in the peace movement. 
the Socialist Party. All these factors were beginning to make an impression on the younger elements in the SP. ${ }^{1}$

The question of entry into the Socialist Party was kept as a very live issue in the American Workers Party by Cannon and Shachtman, much to the chagrin of Muste; by the end of 1935 relations between the two groups were quite strained. Muste was of the opinion that a split in the Socialist Party would open new and bright prospects for the development of the Workers Party as the most important proletarian organization in the United States. Young Trotskyists like Albert Glotzer of Chicago regarded the SP as a hopelessly "reformist" organization which should be fought vigorously by revolutionists and not courted. Cannon and Shachtman who were well aware of Trotsky's problems repeatedly emphasized that the Workers Party should strive for fusion with the left wing of the Socialist Party in order to become a mass organization. ${ }^{2}$

\section{CANNON AND SHACHTMAN SEEK TROTSKY'S APPROBATION}

Towards the end of December 1935 the Socialist Party in New York was thrown into turmoil as both the Old Guard and Militant factions claimed to be the official party organization in the State. Cannon and Shachtman decided that the time for decisive action had arrived and they addressed an urgent communication to Trotsky. They asserted that the Socialist Party was bound to go through a nation-wide split before too long and that the Militants would win control of the national organization. The American Stalinists were making a great effort to turn the situation to their advantage. "There is not merely a potential, but a very real danger that the bulk of the leftward movement in the Socialist Party would be swallowed up, and consequently, vitiated and destroyed, by Stalinists." While the situation was still fluid and indeed favorable, the Trotskyists must enter the SP as a group, Cannon and Shachtman argued.

\footnotetext{
${ }^{1}$ Interviews with Sidney Bleifeld (Los Angeles), Hyman Weintraub, Pearl Weiner, Frank Stern, and Esther Levine (Cleveland), and Virginia Vacirca Brown (New York). The names of towns where the persons interviewed lived during the period under review are given in parentheses. Cannon and Shachtman wrote to Trotsky that often members of the Young People's Socialist League told them, "Why don't you comrades come into the S.P.? ... With your ability you could become leaders of the movement." Cannon and Shachtman to Trotsky, 4 January I936, Cannon Papers.

${ }^{2}$ For the debate between the "Cannon-Shachtman faction" and A. J. Muste, see Max Shachtman, "On the 'Reform' of a Socialist Party", in: Workers Party Internal Bulletin, 22 July 1935; A. J. Muste, "How the Cannon-Shachtman Group Builds the Party", ibid., Io January 1936. The latter issue of the Bulletin also carried two opposing statements evaluating developments in the Socialist Party.
} 
"The fluidity of the official SP at the present time is a factor of exceptional importance. With the hard, homogeneous kernel represented by the Old Guard reformists out of the party, there remains a loose and more or less pliable organization tending toward the left. The task is to gain a position inside this mass before it crystallizes."

Once inside the Socialist Party, Cannon and Shachtman asserted, the Trotskyists had nothing much to worry about. Their trained and resolute cadres were more than a match for the so-called Militants. With the exit of the Old Guard, the SP bureaucracy would be weak and inexperienced. The Party's loose structure would enable the Trotskyists to maintain their own publications and thus carry on their propaganda without a break and, indeed, to a much larger audience. In many states and cities the SP was so inadequately organized that the Trotskyists would become the Socialist Party as far as those areas were concerned.

Cannon and Shachtman did not envisage a very long stay for the Trotskyists inside the Socialist Party. They believed that it would not be possible to capture the SP and, of course, they had little hope that it could be "reformed". To them the Socialist Party was an obstacle blocking the road of the Trotskyists to the masses. Their object was to get into the SP, bring about its downfall and emerge with its revolutionary elements as adherents to the Trotskyist cause. That was the way in which they posed the issue before Leon Trotsky:

"Our problem is: how to clothe the bones of our ideas with the flesh of the masses; how, in the shortest possible space of time, to add to the approximately 1,200-1,500 W. P. and S. Y. L. [Spartacus Youth League - the Trotskyist youth organization] members another one-two-three thousand revolutionary workers. What link shall we pull on, at the given moment, which will draw more of the whole chain into our hands?"

Cannon was especially hopeful that energetic and well-planned action could enable the Trotskyists to capture the youth organization of the Socialist Party-the Young People's Socialist League. "I personally consider the YPSL perhaps the most important aspect of the whole problem, because I consider it feasible and practical to aim at the conquest of this organization for our cause", he wrote to Trotsky. ${ }^{1}$

\footnotetext{
1 Shachtman and Cannon to Trotsky, 4 January 1936; Cannon to Trotsky, ro January 1936, Cannon Papers. "The elimination of the rival organizations from our path, by direct attack and by winning sections of their membership to our ideas, is a necessary and constant phase of our drive toward the masses", Cannon wrote. Workers Party Internal Bulletin, January 1936.
} 
Cannon and Shachtman knew well that Trotsky would not countenance any move aimed solely or even principally at promoting his personal interests. To win his acceptance they needed to present the case in such terms as to make it acceptable to their proud and historyconscious leader. Cannon and Shachtman wanted an immediate reply from the guru and it was in response to their request that Trotsky sent his cable to New York.

Trotsky's telegram strengthened the hands of Cannon and Shachtman in their struggle against some of their own colleagues who had charged that entry into the reformist Socialist Party would be a surrender of their revolutionary objectives. The Old Man, as he was affectionately called by his disciples, followed up his cable with an urgent letter containing the simple message: "act quickly". 1

\section{TROTSKY SENDS DETAILED INSTRUCTIONS}

Trotsky's detailed instructions to Cannon and Shachtman and his repeated emphasis on the need for tact bring out the enormous interest that he attached to the success of the venture. Trotsky advised his followers not to adopt a rigid attitude in dealing with Socialist leaders while negotiating the question of their admission into the SP. On organizational matters they should be prepared to make the most extensive concessions. Once inside the SP, they should proceed with their work cautiously, failing which they would stand exposed prematurely before the Party's leaders and members. They should avoid the mistake of their French comrades who expended too much energy in "phraseological exposure" of the social democratic leaders instead of carrying out organizational work at the base. By means of "quiet" work, Trotskyists should seek to win the younger intellectuals in the $\mathrm{Sp}$ "for our program, for our past, and thereby also for our future."

Trotskyists should also seek to establish fruitful contacts in local organizations of the SP on the basis of common participation in various struggles, the Old Man counselled. They should not lose themselves in side issue which would only provoke irritation, but should concentrate on "well-chosen and important questions". They should be especially careful not to react with mockery and contempt to the dreary platitudes of the Socialist leaders because such a course would make the ordinary SP members hostile towards the newcomers.

\footnotetext{
1 Trotsky to Cannon and Shachtman, 24 January 1936, Cannon Papers. He emphasized that when a tested and stable group like the Trotskyists entered a "centrist" party like the SP, it was in no sense a capitulation. He agreed with Cannon's analysis that the Trotskyists should enter the SP before the centrist leadership of the latter had time to consolidate itself.
} 
"Therefore", emphasized Trotsky, "the greatest endurance, a calm, friendly tone is indispensable. Naturally the tone can and will change when you already have the necessary points of support and when big political questions come upon the order of the day."1

Even as Trotsky's endorsement and counsel were on their way, Cannon set about earnestly preparing the members of his group for what he described as the boldest political move that the Trotskyists had ever undertaken and he demanded that the "firmest bolshevik discipline" must be adhered to in making it a success. In the months ahead, he warned, all Trotskyists must stand ready to respond promptly to central direction because, after entry into the Socialist Party, they would not be able to meet openly as a group except under the most extraordinary circumstances and to discuss the most vital questions. ${ }^{2}$

Cannon then proceeded to establish contacts with leading members of the left-wing group of the Socialist Party - the Militants - and in this objective he was greatly helped by Herbert Zam. Zam, a former Lovestoneite, had entered the SP in 1934 and had established a place for himself as a theoretician for the left-wing. ${ }^{3}$ Through Zam's help Cannon met other members of the Militant group like Gus Tyler, Murray Baron, Andrew Biemiller, and Paul Porter. Even as he negotiated with them in soft and conciliatory tones, as instructed by Trotsky, Cannon loathed them. To him they were "inexperienced and untested, ... ignorant, untalented, petty-minded, weak, cowardly, treacherous and vain. And they had other faults too."4 But he was

1 Trotsky to Cannon and Shachtman, 24 January 1936; Trotsky to Cannon, 9 March 1936, ibid.

2 The Split in the SP and Our Policy, text of a speech given at a closed meeting of members of the Cannon-Shachtman faction, New York, 4 January 1936; Cannon to "Dear Comrades", 4 January 1936, mimeographed; "Letter to a Chicago Comrade", n.d., January 1936, mimeographed, ibid.

${ }^{3}$ Jay Lovestone, executive secretary of the Communist Party of the United States during 1927-29, had been expelled from the Party in June 1929. He then organized the Communist Party (Opposition) and Zam was a member of this group. Lovestone is at present an important functionary of the American Federation of Labor - Congress of Industrial Organizations. Zam made his exit from radical politics in the early ' 40 . When he resigned from the Lovestone group in August 1934 in order to join the SP, Zam declared that he was not departing from communism but striving for a new beginning "in the interests of the international Communist movement". He wanted a Communist Party in the United States in which democracy for members would be real and which would effectively work for revolutionary working class unity. Herbert Zam, “To All Members of the Communist Party (Opposition), 13 August 1934, mimeographed, Documentary Collection of the Socialist Workers Party Library, Los Angeles, California. (The SWP is the current name of the Trotskyist group in the United States.)

4 James P. Cannon, The History of American Trotskyism: Report of a Participant (New York, r944), p. 224. 
able to make satisfactory progress because Zam was always good enough to brief him privately in advance what exactly he should expect. Very soon, thanks to the good offices of Professor Sidney Hook of New York a meeting was arranged between the Trotskyist representatives and Norman Thomas. Hook had placed before Thomas a persuasively argued brief on why the Socialist Party should admit the members of the Workers Party as a group and give them the same privileges and duties as were enjoyed by regular members of the SP. ${ }^{1}$

\section{TROTSKYIST LEADERS MEET NORMAN THOMAS}

Thomas was extremely busy with the controversy with the Old Guard and he paid very little attention to the pros and cons of admitting the Trotskyists into the Socialist Party. He had been advocating an "all inclusive party" for long, but had failed to examine closely the implications of such "inclusiveness" As on many other organizational matters he was content to let his "young men" make the decision for him. The Trotskyist representatives were on their best behaviour during their interview with Thomas and were willing to accept any conditions so long as they could gain entry. The conditions that the Militants demanded were onerous - the Trotskyists would have to come into the SP as individuals and not as a group; they should suspend publication of their own journals, the Militant and the New International. The Trotskyists accepted them without open complaint but with great inner anger and disgust. "A Trotskyist will do anything for the party, even if he has to crawl on his belly in the mud", Cannon said later, in recalling these developments. ${ }^{2}$

The Militants were blissfully unsuspecting in their dealings with the Trotskyists. Little did the Militants realize that the Trotskyists had no intention of treating their agreement with them as sacrosanct. In respect of publications, for instance, the Trotskyist assurance had been given with tongue in cheek because Cannon had already made arrangements to get around it. A Trotskyist named Albert Goldman had broken with his comrades several months earlier and had entered the SP where he had established a journal known as the Socialist Appeal.

"Prof. Hook argued that the Communist Party was going over to "social patriotism" in all countries and that if it captured control of the labour movement in the United States it would lead the drive towards war. Only the entry of the Workers Party with the SP would prevent the latter from being swamped organizationally and ideologically by Stalinism. The SP, said Hook, could also make substantial advances in the cultural field because the Trotskyists would bring to its support such intellectuals as Louis Hacker, Charles Y. Harrison, Max Eastman, John Dos Passos, Lionel Trilling, Lionel Abel and John Chamberlain, along with several well known teachers. Sidney Hook to Norman Thomas and others, n.d., Cannon Papers.

2 Cannon, History, op. cit., p. 226. 
When the Trotskyist perspective became one of entry into the SP, Cannon established contact with Goldman and effected a reconciliation. Goldman agreed to work hand in hand with Cannon in furthering the Trotskyist line through the medium of his journal. The Appeal, while ostensibly a Socialist publication reflecting the left wing Militant point of view, was turned surreptitiously into an organ for furthering the Trotskyist objectives. ${ }^{1}$

Having won approval from the Militants and Thomas for their entry into the Socialist Party, Cannon and Shachtman waged a successful struggle in the convention of the American Workers Party to obtain endorsement of their line. Without the slightest compunction they set about the task of liquidating that organization - thus eliminating one more obstacle on the path of the Trotskyists towards the masses! But the formal obituary notice was not issued till after the crucial national convention of the Socialist Party. At that convention, held in May 1936, the split which the Trotskyists had impatiently awaited became an accomplished fact. The Old Guard Socialists walked out of the convention and announced the formation of a new organization. Immediately afterwards the National Committee of the Workers Party announced the dissolution of the organization and directed its members to join the Socialist Party. ${ }^{2}$

\section{TROTSKYISTS ENTER THE SOCIALIST PARTY}

Trotskyists then began entering the $\mathrm{SP}$ as individuals and members of the Trotskyist Spartacus Youth League joined the Young People's Socialist League (YPSL). The Militants, having just emerged from an enervating struggle with the Old Guard, were in no mood to expend any energy in greeting the newcomers, especially since they regarded the Trotskyists as homeless waifs who had failed to build the Workers Party and had begged to be taken into the SP. "We received no welcome, no friendly salute, no notice in the press of the Socialist Party", Cannon recalled later with evident disgust. "Nothing was offered to us. Not one of the leaders of our party was offered so much as a post as branch organizer by these cheapskates - not one. ... It was a shabby business - the way they received us. If we had been subjective

\footnotetext{
${ }^{1}$ Interview with Cannon. For Goldman's work in advancing the interests of the Trotskyist group see the following notes in his journal: "Workers' Party Splits", in: Socialist Appeal (Chicago), II (November-December, I935), p. 8; "Left Wingers Must be Invited to Join the Party", ibid., II (January-February, I936), p. 8. Goldman, a capable labour attorney, served as 'Trotsky's defence counsel in the course of hearings conducted by the Dewey Commission.

2 "Statement of National Committee" [of the American Workers Party], in: New Militant (New? York), II (6 June I936), p. I; "Workers Party Calls All Revolutionary Workers to Join the Socialist Party", ibid., pp. 1, 3.
} 
people standing on our honor, we might have said, 'To hell with it!' and walked away. But we didn't, because we were serving political ends." 1 From June till November 1936 the energies of the Socialists were absorbed in the presidentical campaign in which Norman Thomas was again the Party's standard bearer. The Trotskyists were not given any significant responsibility in connection with the campaign but they remained models of propriety despite such neglect.

\section{THE FIRST MOSCOW TRIAL: TROTSKY SEEKS ASYLUM IN MEXICO}

Cannon's willingness to put up with what he regarded as gross indignities was undoubtedly in response to the advice from Trotsky based on the latter's evaluation of fast-moving developments in the Soviet Union. The Trotskyist manoeuvre of entry into the Socialist Party had been successfully implemented just in the fnick of time. Stalin was even then setting the stage for what has rightly been described as "the longest St. Bartholomew's night in history", lasting for three years. The indescribably brutal and inhuman "Yezhovshchina" was about to be inaugurated by the master of the Kremlin. ${ }^{2}$ On 14 August 1936 the People's Commissariat of Home Affairs of the Soviet Union announced the "discovery of a number of Trotskyist-Zinovievist terrorist groups preparing terrorist acts against the leaders of the Communist Party of the Soviet Union and the Soviet State, under the direct instructions of Trotsky..." On I9 August Zinoviev, Kamenev, and six others were brought to trial and the world watched the eerie drama of the comrades of Lenin pleading guilty to all the charges levelled against them and being sentenced to death six days after the start of the trial. ${ }^{3}$

Communist newspapers of all countries, taking their cue from

${ }^{1}$ Cannon, History, op. cit., p. 232.

2 For the Stalinist version of the events of this period see: Commission of the C. C. of the CPSU (B), ed., History of the Communist Party of the Soviet Union, Short Course (Moscow, 1949), pp. 400-06, 427-29. For Nikita Khrushchev's version see: History of the Communist Party of the Soviet Union (Moscow, 1960), Pp. 512-13. Trotsky's own detailed appraisal of the trials is to be found in his concluding statement before the Commission of Enquiry headed by Prof. Dewey. Text in: Leon Trotsky, Stalin's FrameUp System and the Moscow Trials (New York, 1950). Also useful is the account given by the veteran Russian social democrat, Raphael R. Abramovitch, in: The Soviet Revolution I91 7-1939 (London, 1962), pp. 390-423.

3 People's Commissariat of Justice of the USSR, Report of Court Proceedings, The Case of the Trotskyite-Zinovievite Terrorist Centre (Moscow, 1936). "I demand that dogs gone mad should be shot - every one of them", declared A. Y. Vyshinsky, the prosecutor, in his final oration to the court. Ibid., p. I64. On I 9 August Pravda carried an article by $a$ rising figure, Lavrenti Beria, asserting that "the enemies of socialism must be crushed into dust". In a collective letter, Soviet writers declared that the traitors should be "wiped off the face of the earth". Cited in Abramovitch, op. cit., p. 398. 
Moscow, mounted a campaign of ferocious virulence against Trotsky and his alleged partners in terrorism. The General Secretary of the Comintern, George Dimitroff, declared in an article in Pravda that "to defend the despicable terrorists means to help fascism." On 30 August the Soviet Union called upon the Norwegian government to deport Trotsky on the ground that the latter was organizing terroristic activities. The demand was rejected, but the Norwegian government was apparently so alarmed over the consequences of Soviet displeasure that it promptly imposed drastic limitations on Trotsky's movements and activities. "It was a prison in every respect", the exile recalled subsequently. "We could not leave the house and courtyard. We could not correspond, and we could not have visitors. It was worse than a Tsarist prison because in the Tsarist prison we had visits from friends and from my relatives. Here, I had no visits at all. All correspondence passed through the police." 2

Under these restrictions Trotsky could not have the slightest hope of working for the establishment of an international commission of enquiry. Contact with his adherents in various parts of the world and rebuttal of the continuing Stalinist barrage became extremely difficult. In addition to these considerations, his adherents in the United States were gravely concerned over the personal safety of the Old Man, especially after the Norweigan government announced that it would not renew his visa. Expulsion from Norway and possible arrest by Stalin's GPU were very real possibilities. No country in Europe was willing to offer asylum to the fiery preacher of world revolution and no different response was expected from the United States of America.

Faced with such an extremely critical situation, Trotsky's friends made feverish efforts to find him a haven in Mexico where the independent radical, Lazaro Cardenas, was the chief executive. The Communists of Mexico and the chief of the powerful Mexican Confederation of Labour, Lombardo Toledano, violently opposed the move. On 3 December Norman Thomas, along with a few other Americans, sent a cable to Cardenas earnestly urging the grant of asylum to Trotsky. ${ }^{3}$ Six days later the Bolshevik exile received a

\footnotetext{
${ }^{1}$ Quoted in Francis Heisler, The First Two Moscow Trials: Why? (Chicago, 1937), p. 7. The volume was published by the Socialist Party of America with a preface by Roy E. Burt, executive secretary.

2 Statement by Trotsky, in: The Case of Leon Trotsky: Report of Hearings on the Charges Made Against Him in the Moscow Trials by the Preliminary Commission of Inquiry (New York, 1937), p. 38. Also Max Shachtman, Behind the Moscow Trial (New York, 1936), pp. I33-42.

3 Thomas and others to President Cardenas, 3 December 1936, Norman Thomas Papers, New York Public Library.
} 
Mexican visa and on 9 January 1937 he disembarked from a cargo ship at the Mexican port of Tampico.

While these dramatic events were taking place American Trotskyists deemed it of crucial importance to appear in the role of loyal members of the Socialist Party and to avoid any action that could arouse the misgivings of the important leaders of the SP. An American Committee for the Defense of Leon Trotsky had been established and Norman Thomas' active membership in it was deemed vitally important by the Trotskyists. None of them could hope to secure the kind of attention which the American press and bourgeoisie usually accorded to the Socialist leader. And, Norman Thomas, dedicated upholder of civil liberties and the rights of man, spoke out forcefully against the blood bath in the Soviet Union. Stalin's actions, he declared at a well attended meeting in New York City, revealed a ruthless hate and intolerance that tended to destroy "the basis for a fellowship of free men". ${ }^{1}$ Even as the cargo boat carrying Trotsky was on the high seas Thomas raised the issue of the appointment of an international commission to investigate Stalin's charges. "I am interested...to get at the truth, factually and historically. It is a very serious matter for a man like Trotsky to rest under such charges", he said. ${ }^{2}$

Things were working out exactly as Trotsky and his coadjutors had hoped and Cannon and Shachtman were content to remain discreet and uncomplaining.

\section{TROTSKYISTS WOO LEFT-WING MILTTANTS}

The Trotskyist leaders were, however, by no means inactive. Jim Cannon's prescription to his men was clear and precise: "Penetrate the organization, become integrated into the party, plunge into practical work and thus establish a certain moral authority with the rank and file of the party; establish friendly personal relations, especially with those elements of the party which are activists and therefore potentially of some use."3 That was exactly what the Trotskyists proceeded to do with considerable success. Cannon himself

1 New York Times, 19 December 1936, p. 8.

2 Ibid., 27 December 1936, p. 3.

${ }^{3}$ Cannon, History, op. cit., p. ${ }^{239}$. In places like New York and Wisconsin where the SP had reasonably well-organized machines and where Socialist office-beaters had first hand knowledge of Trotskyists, the latter were unable to make headway in winning Party offices. For this reason they concentrated their attention on entrenching themselves in organizations in other important states where the Party bureaucracy was not especially strong. In many such state organizations Party work was often in a state of suspended animation. The Trotskyists appeared on the scene and evinced readiness to devote their time unstintingly to even such work as was regarded as drudgery by others. They thus made themselves indispensable and soon were able to get themselves elected to Party positions. Interviews with Hyman Weintraub (Cleveland), Albert M. Glotzer (Chicago). 
went to California and soon launched a weekly newspaper under the name of Labor Action as the official organ of the State Socialist Party. Glen Trimble, secretary of the Socialist Party of California, was soon won over by Cannon to the Trotskyist cause. In the youth organizations too the Trotskyist influence steadily increased and before long Ernest Erber, national chairman of the Young People's Socialist League, became a convert.

The very low vote polled by the Socialist Party in the presidential election of 1936 revived the old controversies on what exactly the tactics of the Party should be in the months that lay ahead. Serious differences on the subject arose among the New York Militants - a development that greatly heartened the Trotskyists. Jack Altman, executive secretary of the New York Local, believed that with the ouster of the Old Guard, the SP had become a left-wing organization and that the most important task before the members was to settle down to the business of extending the Party's influence in the political and trade union fields. He was supported by such Militants as Murray Baron, Sam Baron, Murray Gross, Hal Siegel, and Aaron Levenstein. Others like Herbert Zam and Gus Tyler were, however, firmly of the view that the Party should not be deflected from its revolutionary struggle for socialism by the hope of minor gains in the political or trade union spheres.

Recognizing that Altman commanded the support of a majority of the membership of the New York Local, Zam and Tyler favoured collaboration with the Trotskyists to bring into existence a new left wing that would combat what they regarded as "reformist" tendencies in the Socialist Party. Understandably enough, the Trotskyist leaders were very receptive to the idea and readily agreed to support the programme of the Zam-Tyler group. The Trotskyists realized that opposition to their ideology and programme was bound to emerge principally from the SP officials of New York and Wisconsin - two areas where the Party had some mass base, some political influence and some contacts with organized labor. Very early they recognized that their most formidable opponent would be the canny and energetic Jack Altman of the New York City Local. The Trotskyists were not afraid of Socialist leftwingers like Zam and Tyler; they regarded the latter as incapable of either building cadres or acting in decisive fashion. ${ }^{1}$

1 Interviews with Cannon and Shachtman. Zam and Tyler to Ben Fischer, 2 October 1936, Archives of the Socialist Party of America, Manuscripts Division, Duke University Library, Durham, North Carolina. Altman subsequently broke with the SP on the question of aiding the Allies: he was an active trade unionist in New York till his death some time ago. Gus Tyler, collaborator of Zam and opponent of Altman, is now educational director of the International Ladies' Garment Workers Union. 
As soon as the national elections were over, Zam organized in New York a "Revolutionary Socialist Educational Society" and the Trotskyists promptly announced their support for it. Altman interpreted the move as a challenge to his leadership in the New York City organization. At his instance the New York City Central Committee of the Party adopted a resolution placing a number of restrictions aimed at paralyzing the Revolutionary Socialist Education Society. Zam and Tyler were indignant at this action and the Trotskyists endeared themselves to the former by loudly condemning Altman in the Socialist Appeal. ${ }^{1}$

\section{"CLARITY" FACTION FAVOURS COLLABORATION WITH TROTSKYISTS TO THWART "RIGHTISTS"}

To the great satisfaction of the Trotskyists, the differences between the "Altmanites" - as the supporters of the executive secretary of the New York Local came to be called - and the group led by Zam and Tyler continued to mount as the Socialist Party's attitude towards the American Labor Party (ALP) became an important issue in New York. The ALP had been launched in New York by an influential group of liberals, trade union leaders, and former Old Guard Socialists. Altman saw the possibility of electing one or two Socialists to the New York City Council by working out an electoral arrangement with the American Labor Party. If the SP insisted on running its own slate of candidates against the ALP, it would gravely antagonize organized labor which was energetically backing the ALP, Altman argued.

Bitterly attacking this view as a rehash of the Old Guard line, Zam and Tyler asserted that the SP should associate itself only with a labour party committed to a programme of independent political action on a clear cut working class programme. ${ }^{2}$ In their interpretation of the implications of the New York developments, Zam and Tyler were supported by Maynard Krueger, David Felix, and Robert Delson, members of the National Executive Committee, and Frank Trager, Labor Secretary. Gradually these men became convinced that they should organize their own caucus both in the Party and in the YPSL in order to make their point of view prevail. Thus was born the group that came to be known as the "Clarity" caucus. In contrast to the

1 "The Left Wing Stands for Its Rights in New York", in: Socialist Appeal, II (I ) December 1936$)$, p. 9.

${ }^{2}$ Against Participation in the Republican-Fusion-Communist Alliance for La Guardia! Statement of the Minority of the New York Municipal Campaign Committee of the Socialist Party (Max Delson and Herbert Zam), mimeographed. William Goldberg-Hyman Weintraub Collection of Socialist Party Documents. The Collection is in the custody of Dr. Hyman Weintraub, East Los Angeles College, Los Angeles, California. Goldberg and Weintraub were active members of the YPSL during the period under review. 
Altmanites and the Wisconsin group who, Zam argued, were inclined to dabble in unsavoury deals with capitalist politicians and reactionary labour leaders, the Trotskyists, while undoubtedly sectarian in their outlook, were true revolutionists. Differences with the Trotskyists, he emphasized, "could be settled in the course of events in comradely fashion". 1

\section{REACTION AGAINST TROTSKYIST "EDUCATIONAL" CAMPAIGN}

The Altman-Clarity dispute augured well for the success of Trotskyist plans to make themselves a significant factor in the Socialist Party. Unfortunately, however, their flexibility was affected by developments in Spain and Russia on which they felt impelled to take a "principled stand". ${ }^{2}$ The Trotskyists felt that it was their duty to conduct an intensive "educational" campaign in the Party on the issues posed by the Spanish Civil War and the Moscow trials. Articles by Trotsky in the Socialist Appeal set the tone for the campaign. "We want", Jim Cannon had written to Trotsky, "to begin from the start to accustom the Socialists to your intervention on the most important political questions."3

1 Zam to "Dear Comrades," is February 1937, mimeographed, Cannon Papers. Trotskyists also opposed any alliance with the ALP on the ground that it was a mere ruse by discredited capitalist politicians and "labor-fakers" to head off the growth of a revolutionary Socialist Party. See, "Prospects for a Labor Party", in: Socialist Appeal, III (February, 1937),pp. I 5-16; Should Socialists Build a Farmer-Labor Party? ibid., pp. 17-19. 2 The Trotskyists opposed the whole concept of "popular frontism" in Spain as a sinister manoeuvre of Stalinism and loudly expressed their support for the POUM group which was widely regarded as friendly to Trotsky. The SP's line, as formulated by its National Executive Committee, was one of support to the Popular Front and especially to the Left Socialists in it led by Largo Caballero. See M. S. Venkataramani, "American Socialists, the Roosevelt Administration, and the Spanish Civil War", in: International Studies, III (April, I962), pp. 395-424.

${ }^{3}$ Cannon to Trotsky, 19 February 1937 , Cannon Papers. Early in January 1937 the Trotskyists established the Socialist Appeal Association with headquarters in Chicago "to educate party membership in the principles of revolutionary Socialism." They then issued a call for an "Appeal Institute" to be conducted in Chicago in the third week of February 1937 "to discuss the situation in the national left wing movement [and]... prepare the forces for the convention." Over a hundred representatives from 12 states participated in the proceedings of the "Institute" and Zam and Trager were on hand as observers from the Clarity group. The latter made it clear in their speeches that they could not agree with many points in the programme of the Appeal group and that their own caucus would continue to struggle against both left and right elements in the Party. The Trotskyists, in line with their strategy of continuing to placate the Clarity group, secured the adoption of a resolution asserting that the surest way to assure the growth of the SP would be through the unification of the left wing "which means above all unity between the Appeal and Clarity groups." Minutes of the Socialist Appeal Institute held in Chicago, 20-27 February 1937, mimeographed, Cannon Papers. Interviews with Cannon, Shachtman, and Glotzer. Also Albert Goldman, "The Appeal Institute", in: Socialist Appeal, III (March, 1937), pp. 36-39; Resolutions Adopted at Appeal Institute, ibid., p. 4o. Cannon, History, op. cit., pp. $245-7$. 
In branch and local meetings Trotskyists repeatedly brought up the "Spanish question" and the "Russian question" for discussion in a manner that annoyed many Socialists. Critics pointed out that the Trotskyist condemnation of the Popular Front government in Spain was contrary to the official line of the Socialist Party. Others regarded the persistent attacks of the Trotskyists against Stalin as part of a campaign of vilification against the Soviet Union itself. In many New York branches of the Party there were frequent squabbles as Altmanites protested against the Trotskyist tactics. The Wisconsin organization also was critical of the "indiscipline" of the Trotskyists. Altman complained to Norman Thomas that the Trotskyist activities were gravely interfering with the Party's work in New York. From Wisconsin another Thomas confidant, Paul Porter, wrote that the Trotskyists were proving to be incorrigible and that the question of expelling them should be seriously considered at the next convention of the Party. ${ }^{1}$ The Communist Party of the United States was also virtually hysterical in its sollicitude for the SP and continually urged the latter to eliminate the "poisonous influence" of Trotskyism. ${ }^{2}$

\section{THREAT OF EXPULSION FROM SP: TROTSKY'S REACTION}

Cannon and Shachtman took note of these developments and were deeply disturbed. Expulsion from the Socialist Party was the last thing that they wanted at that time. The work of the American Committee for the Defense of Trotsky was nearing a critical stage. The situation was greatly complicated by a second trial that Stalin had staged in Moscow with tremendous fanfare during 23-30 January 1937. Y.L.Pyatkov, K.B. Radek, and fifteen other veteran leaders of the CPSU (B) were accused of being members of an "Anti-Soviet Trotskyite Centre" that had engaged in espionage and wrecking activities. As in the previous trial all the accused pleaded guilty to all the charges and pointed to Leon Trotsky as the mastermind behind a conspiracy to destroy the Soviet Union in collaboration with the Nazis. In its verdict the military court branded Trotsky as an "enemy

\footnotetext{
1 Jack Altman, Murray Baron, Aaron Levenstein, Sam Romer, Brendan Sexton, and others to "Dear Comrades", 1o February 1937, Daniel W. Hoan Papers, Milwaukee County Historical Society, Milwaukee, Wisconsin. Hoan, major of Milwaukee, was an important leader of the Socialist Party. Paul Porter, Which Way for the Socialist Party? (Milwaukee, 1937), pp. 40-4I.

2 See, for instance, report of speech by Earl Browder, General Secretary of the Communist Party (USA) in Madison Square Garden, New York Times, 21 January 1937, p. 9. Also Earl Browder, The People's Front (New York, I938), pp. 27, 1 28, $210-16$.
} 
of the people" who had engaged in treacherous activities. ${ }^{1}$ The show of legality with which the trial was conducted and the despatches of Western correspondents to the effect that the "sincere confessions" of the accused appeared to be entirely voluntary, led many to wonder whether indeed Trotsky might not be guilty as charged. One of the members of the American Committee for the Defense of Leon Trotsky, M. A.Hallgreen, associate editor of the Baltimore Sun, resigned from the Committee asserting that he was convinced hat the defendents in the Moscow trial had clearly been proved guilty. ${ }^{2}$

Under these circumstances Trotskyist leaders were exceedingly anxious not to endanger their position as members of the Socialist Party. The Commission of Inquiry that Trotsky had vainly demanded for five long years had finally come into existence with the respected American educator, Prof. John Dewey, as Chairman. ${ }^{3}$ Arrangements were under way for the Commission to visit Mexico early in April to hear Trotsky's testimony. A special national convention of the Socialist Party was scheduled to be held towards the end of March.

\footnotetext{
${ }^{1}$ People's Commissariat of Justice of the USSR, Report of Court Proceedings in the Case of the Anti-Soviet Trotskyite Centre, Verbatim Report (Moscow, 1937). For Stalin's own slashing attacks on Trotskyist "wreckers, diversionists, spies and murderers" who were "acting on instructions from intelligence service organs of foreign States", see texts of speeches delivered by him at the Plenum of the Central Committee of the Communist Party of the Soviet Union, 3 and s March 1937 , reprinted in: Z. P. Coates and Zelda K. Coates, The Moscow Trial (London, 1937), pp. 249-8I.

2 For Hallgreen's comments and the reply of Suzanne LaFollette, see New York Times, 5 February 1937, p. 20; 8 February 1937, p. 16. Hallgreen declared that the American Committee for the Defense of Leon Trotsky appeared to be aiding the Trotskyists, "perhaps unwittingly", in their efforts to destroy the present Soviet Government. "That I regard as an attack upon Socialism and upon the Socialist system now being created in the Soviet Union. ...I have no intention of becoming a party to any such arrangement." The Communists and their sympathizers hailed Hallgreen's resignation enthusiastically. 3 The Commission was composed of the following members: John Dewey, Professor Emeritus of Philosophy, Columbia University; John R. Chamberlain, writer and literary critic; Alfred Rosmer, member of the Executive Committee of the Communist International I920-I and editor-in-chief of l'Humanité, I 923-24; Edward Alsworth Ross, Professor Emeritus of Sociology, University of Wisconsin; Otto Ruehle, former Social Democratic member of the German Reichstag; Benjamin Stolberg, labour journalist; Carleton Beals, author and educator; Wendelin Thomas, Independent Socialist and later Communist member of the German Reichstag, 1920-24; Carlo Tresca, Anarcho-Syndicalist leader and editor of the Italian newspaper, il Martello of New York; Francisco Zamora, editorial writer on the newspaper El Universal of Mexico City; and Suzanne LaFollette, writer and journalist. John R. Finerty who had served as counsel to the accused in two celebrated American "class war" cases, the Sacco and Vanzetti case and the Tom Mooney case, was named counsel for the Commission. Fuller details concerning the "commissioners" can be found in an appendix in: Trotsky, Stalin's Frame-Up System, op. cit., pp. 133-34. Carleton Beals resigned from the Commission while the inquiry was still in progress and did not sign its final report.
} 
Cannon and Shachtman concluded that it was absolutely essential to ensure that the Trotskyists were not expelled by the convention. "It is quite clear to me... that our task in the SP is by no means completed or exhausted", Cannon wrote to his adherents in New York. He added:

"We need more time to win over larger sections of the party, to say nothing of welding the left socialists closer to us. We cannot yet be sure of too many of them standing firm under the concentrated blows of the right wing, especially if they are dealt by convention majority and the penalty of adherence to us is expulsion."

Cannon urged that, under the circumstances, the Trotskyists should try every possible means of arriving at an understanding with the Clarity group. Much would also depend on the attitude of Norman Thomas which might have a determining effect on even the Zam group. The Trotskyists should, therefore, play for time. "I am inclined strongly for a temporizing tactic and conciliatory approach to Thomas. We must have more time if we can gain it without paying too high a price for it." 1

Cannon mentioned these problems in a letter to the master himself and the latter's reply was very skillfully worded. Undoubtedly Trotsky himself was extremely interested in the work of the Defense Committee and especially of the move for the setting up of a Commission of Inquiry. At the same time he did not want to give the impression that he would allow personal considerations to stand in the path of any principled political action that the Trotskyists might have to embark on. Trotsky told Cannon that it would be "absolutely childish on our part to cherish illusions about the firmness of such fellow-travellers [as Norman Thomas]; a simple liberal can be firmer than a Social-Democrat in matters of justice." If Thomas posed any issue on the basis of principles, then Cannon should not avoid "accepting the plane of principles and fighting on this plane with the utmost energy." But a rupture with Thomas "in this situation" would be disagreeable and prejudicial from the point of view of the Defense Committee. Cannon should, therefore, maintain towards "a very firm and undeviating attitude (with all the necessary tact, of course, of course, of course)". ${ }^{2}$

\section{CANNON IMPLEMENTS TROTSKY'S LINE}

Armed with such advice from his preceptor, Cannon worked mightily to prevent the threat of immediate expulsion, brushing aside criti-

1 Cannon to "New York", 3 February 1937, Cannon Papers.

2 Trotsky to Cannon, 9 March 1937 , ibid. 
cisms from some members of his own group who continued to harp on the theme that he was compromising principles for expediency. ${ }^{1}$ From San Francisco Cannon travelled hastily to New York where he was reinforced by Vincent Dunne, the Minneapolis teamster and Trotskyist veteran. The two were sweetly reasonable at a meeting held in Norman Thomas's house. In addition to Gus Tyler, Altman, Baron and a few others were also present. A long discussion ensued and Thomas appealed for harmony and unity among leading members of the Party. He wanted an assurance from the Trotskyists that they would refrain from talking too much at branch meetings and prolonging discussions endlessly. If that was all that Thomas wanted to demand, the Trotskyist representatives were willing to give a solemn assurance. "We made a number of other sweeping concessions of this type", Cannon wrote ironically about this strange encounter. "We wanted peace and we offered quite a few things here and there about the question of positions, and in general were so conciliatory and inoffensive that we finally got an agreement." Thomas assured them that no proposal would be made at the convention to expel any member on the basis of his opinions. ${ }^{2}$ Cannon had won his objective and the danger of expulsion at the convention was overcome.

\section{THE CONVENTION}

In the convention, held in Chicago in the last week of March I937, the Clarity group was able to emerge as the most important bloc and the resolutions that were adopted bore the imprint of its views. Cannon

1 The Trotskyists, while undoubtedly remarkably disciplined as a group, were also beset by a tendency to carry on interminable controversies among themselves. Trotsky himself was so perturbed by reports of such differences that he strongly urged that they should be settled by personal discussion. Shachtman to Cannon (after an interview with Trotsky), 20 January 1937; Vincent Dunne to Cannon, I February 1937; Dunne to Arne Swabeck, I February 1937; Cannon to Dunne, 6 February 1937, Cannon Papers. An account of the anti-Cannon manoeuvres of some of the Trotskyists during this whole period is to be found in articles published in the internal organ of the Trotskyist group following its exit from the Socialist Party: Internal Bulletin of the Organizing Committee for the Socialist Party Convention (October, 1937), pp. II-29, 30-33. So disciplined were the Trotskyists that the controversies that raged in their ranks never came to the attention of other groups in the SP.

2 Cannon, History, op. cit., pp. 247-48. Also mimeographed statement issued a few months later by Gus Tyler: Systematic Falsification - the Trotskyists Contribution to Revolutionary Socialism, July 1937, Goldberg-Weintraub Collection. Cannon's assertion in his History that the special convention was "engineered" by Thomas, Altman, Porter and others for the "special purpose of expelling the Trotskyists" appears to be without basis and is in contradiction with his own description of the episode. After the convention Trotskyist orators began to assert that the SP's right wing, assisted by the Stalinists inside and outside the Party tried to expel their group but failed to do so because the delegates to the convention were against the "splitters". This too was a rather slanted account. 
and other Trotskyist leaders were eager and willing to help; Zam and Tyler, in turn, were anxious to ensure that the resolutions would give expression to the truly "revolutionary spirit" that, in their opinion, the two groups shared. While, in general, happy at the turn of events at the convention, the Trotkyists had reason to be disturbed on two issues. The Clarity group, eager to establish its own dominance in all levels, proposed that the Party press must be under proper disciplinary control. A resolution adopted by the convention stipulated that all factions in the Party should liquidate their factional journals so that the Socialist Party could speak with one voice before the public through the official organ, the Socialist Call. The Trotskyists were enraged by the decision because it meant the end of the Socialist Appeal. ${ }^{1}$ However, they wanted to make no trouble and they realized that they would be decisively defeated even if they chose to oppose it. Cannon was also disturbed when the Clarity leaders asked him not to press for the inclusion of any of his adherents in the National Executive Committee because the New York and Wisconsin delegations were totally opposed to the presence of any Trotskyist on the Party's highest policy making body. Again the Trotskyist leader swallowed his pride and saw the Clarity group succeed in winning a dominant position both in the National Executive Committee and its standing committee, the National Action Committee (NAC). ${ }^{2}$

Thus ended the special convention of 1937 with a show of apparent harmony because no deep cleavages were brought into the open and no group was expelled. There was, however, a vagueness concerning some of the actions of the convention that boded ill for the future. The Spanish issue and the labor party issue, for instance, were of intense interest to the Trotskyist and Altman groups respectively. The Clarity adherents in the NEC apparently did not labour under any misgivings as the curtain was rung down on the convention. They were favourably impressed by the "responsible co-operation" that they had received from the Trotskyists. They noted that Max Shachtman had publicly acknowledged that the convention was a "distinct step forward towards converting it [the Party] into an effective revolutionary instrument in the class struggle..." Surely under the

\footnotetext{
1 For the resolutions adopted at the convention see Socialist Call (New York), III (Io April 1937), pp. I, 12; (17 April 1937), pp. 1, 6. Cannon asserted many years later in his History that during the pre-convention negotiations Thomas had specifically agreed that no attempt would be made at the convention to suppress "internal opinions". He charged that Tomas broke his word subsequently - yet another instance to prove, according to Cannon, the rottenness of "social democratic morality".

2 Gus Tyler, "The Socialist Convention Lays Basis for Rooting Party in Mass Struggles", in: Socialist Call, III (ro April r937), pp. 2, 6; Samuel Romer and Hal Siegel, "Advance in Chicago", in: American Socialist Monthly (New York), VI (May, 1937), pp. 9-12.
} 
influence of Clarity theoreticians the Trotskyist were giving up their sectarianism and becoming useful allies in the struggle to make the Socialist Party a truly revolutionary organization. So the Clarity leaders thought. ${ }^{1}$

Norman Thomas was pleased by the harmony that prevailed in the convention. Before setting out on a journey to Europe, Thomas wrote that the resolution unanimously passed by the convention suspending all factional organs was a favourable augury for the future. "If the same spirit can prevail in Locals and Branches we shall have done a service not only to the Party but to the working class movement. We shall vindicate internal democracy as against organized factionalism, and we shall show that it can work."'2 But Leon Trotsky had entirely different views concerning the Socialist Party. Within a few weeks the Old Bolshevik despatched to his American followers a detailed plan of operations for wrecking the Party that had given them an asylum.

\section{DEWEY COMMISSION HEARS TROTSKY}

A few days after the Socialist convention concluded, the great event for which Leon Trotsky had ceaselessly striven finally materialized. A subcommission of the Commission of Inquiry led by Prof. John Dewey was scheduled to hold hearings on the charges made against Trotsky in the Moscow trials on 10 April 1937. The depth of anguish that the exiled Bolshevik experienced over the years on this matter could be gauged from his exclamation before the Commissioners: "The day I received the telegram about the creation of your subcommission was a great holiday in my life."3

Dewey had asked the Communist Parties of the United States and of Mexico to nominate representatives to attend the hearings and to cross-examine Trotsky. He also invited, among others, Alexander Troyanovsky, the Soviet Ambassador in Washington, and Lombardo Toledano, leader of the Mexican Confederation of Labour and a Stalin partisan, to take part in the proceedings. The invitations were declined - and for good reason. ${ }^{4}$ To face the redoubtable Trotsky in

' Max Shachtman, "Towards a Revolutionary Socialist Party", in: American Socialist Monthly, VI (May, 1937), pp. 13-18.

2 Norman Thomas, "At the Front", in: Socialist Call, III (3 April 1937), p. 12.

3 The Case of Leon Trotsky, op. cit., p. 584.

4 For the correspondence on this matter see, ibid., pp. 594-603. The CP (USA) did not even acknowledge the invitation but the response of Communists in general to Dewey's move was similar to the reply made by the Communist Party of Mexico. Declining to participate "in this Trotskyist comedy", Hernan Laborde, Secretary General of the Mexican CP wrote: "The Political Bureau of the Central Committee of our Party has resolved to decline the invitation... of what is evidently a prejudiced group of declared friends or captives of Trotsky who have previously decided to absolve him of his crimes and to offer him an occasion to renew his attacks on the Soviet Union and his campaign against the anti-fascist popular front." 
combat, to pit their past against that of the builder of the Red Army, and to match their wits with those of the sharpest polemicist of modern times was an experience for which the satraps of Stalin had no especial taste. "Dragged into the light of day, the Stalinists are not fearsome", the defiant Trotsky declared scornfully. "... I will welcome the most venomous questions from the Stalinists; to break them down I have only to tell what actually happened.... the conscience of the world cannot be bribed and...it will score, in this case as well, one of its most splendid victories", he asserted. ${ }^{1}$

For seven days Trotsky told his story to the "Commissioners", passionately denying all the accusations levelled against him during the Moscow trials. His final statement summing up his "case" was a truly masterly performance. "Anything I can say will be an anticlimax", Dewey remarked, as he brought the hearing to a close. ${ }^{2}$

Trotsky himself was apparently profoundly impressed with his own performance and he became convinced that the report of the Dewey Commission was bound to be favourable to him. He believed that his testimony and the report of the Commission would, when published, represent a crushing blow against the Moscow Thermidorians. The Commission had hardly left Mexico when Trotsky began to chafe at the unaccustomed restraint that he had imposed on himself in order to ensure a favourable atmosphere for the Commission's work. No longer did he feel any strong desire that his loyal colleagues in the United States should remain under the tutelage of the social democrats for whom he had such great contempt. And as the cloistered prophet of Coyoacan surveyed the world situation - in Spain, the Soviet Union, Germany and elsewhere - he apparently reached the conclusion that events were unfolding in such a way as to make it imperative for American Trotskyists to emerge forcefully in the open, holding aloft the banner of a revolutionary Fourth International. One year earlier, even while he advised his American followers to use patience and tact with the social democrats in order to win the objective of entry into the SP, Trotsky had asserted: "Naturally... [our] tone can and will change when you already have the necessary

1 Ibid., p. 584 .

2 Ibid., p. 585 . While the hearings were in progress one of the members of the subcommission, Carleton Beals, resigned asserting that he did not "consider the proceedings of the Commission a truly serious investigation of the charges." Beals had asked whether Trotsky had sent Borodin to Mexico in I 9 I 9 as his secret emissary to set up the Communist Party of Mexico. Beals said that the information came from Borodin himself. Trotsky characterized the statement as false and bluntly demanded whether the question was being posed simply to cause embarrassment for him in Mexico. Members of the subcommission were also of the view that Beals' line of questioning was improper. Ibid., pp. 4 I $2-\mathrm{r} 7$. 
points of support and when big political questions come upon the order of the day."1

The tone of the American Trotskyists changed strikingly almost immediately after the conclusion of the Dewey Commission's labours in Mexico. The "big political question" on which the Trotskyists chose to change the tone concerned an event that took place several thousand miles away from the United States - in distant Spain.

\section{REVERBERATIONS OF AN UPRISING IN BARCELONA}

In Spain an insurrection by the POUMist and anarchist workers was brutally suppressed by the Republican government. The international Communist apparatus loudly proclaimed that the uprising was an example of Trotskyist-inspired sabotage of the anti-fascist struggle. Trotskyists asserted that the real target of the Communist attack was not the POUM but Leon Trotsky and that the campaign against the POUM was only part of the grand design to smear Trotsky as an agent of the fascists. The Spanish question thus became a "principled issue" to the Trotskyists on which they could brook no compromise with any group that took a different stand. When the National Executive Committee of the SP adopted a resolution on the Spanish question that was not a complete endorsement of this line, the Trotskyists turned on the Committee with blazing fury, to the great surprise and consternation of the Clarity group. ${ }^{2}$

The matter came up at the meeting of the NEC held in Philadelphia in May 1937. Ironically enough the Clarity group went all out to foil a move by its New York opponent, Jack Altman, to force the Trotskyists out of the Party by indirect means. Altman proposed that the Party should withdraw its endorsement of the Trotsky Defence Committee since its work was practically completed. Such action, Altman hoped, would so infuriate the Trotskyists that their exit from the Party would be speeded up. ${ }^{3}$ However, Frank Trager, Gus Tyler, and David Felix of the Clarity group denounced the proposal and the NEC voted by a decisive majority to continue its endorsement of the Committee. The NEC also adopted a resolution on Spain expressing unstinting support to the Caballero government while reserving the right to criticize it for its failures to follow a thorough-going pro-

1 Trotsky to Cannon and Shachtman, 24 January I936, Cannon Papers.

2 In Spain the application of Stalin's line had meant violent Communist attacks on the Anarchists and the POUMists who were characterized by the Communists as traitors and Trotskyists. For the Barcelona uprising and the story of the Communist outrages against the POUM, see Hugh Thomas, The Spanish Civil War (New York, I96r), pp. 424-29, 452-55.

${ }^{3}$ In the NEC only Alfred Baker Lewis (Massachussetts) and Max Raskin (Wisconsin) supported Altman's plea. 
gramme of social revolution in Spain. On the issue of the Barcelona uprising the resolution declared: "We are firmly opposed to insurrection against the government over differences of policy in this period of civil war. We are likewise opposed to repressive methods by the government against any working class organization which is fighting loyally to defeat the Fascist foe". ${ }^{1}$

After the NEC meeting a group of Clarity leaders had a secret meeting with Trotskyists representatives in New York. Zam, Trager, and Delson who represented the Clarity caucus apparently expected warm gratitude from the Trotskyists for the defeat they had inflicted on Altman in the NEC meeting. They wanted to concert plans for further collaboration between the two groups to wrest control of the New York Local from the Altman group at the City convention of the Party scheduled to be held shortly thereafter. The Trotskyist group consisting of Max Shachtman, James Burnham, Martin Abern and Joe Carter received the proposals somewhat coldly. Shachtman stated that despite past disappointments, his group would be willing to collaborate with Clarity to oust Altman. At the same time he would "serve notice" on Clarity that the Trotskyists would make a determined attempt to bring about a reversal of the NEC's resolution on Spain. The Clarity representatives failed to realize the full implications of the "notice" that was thus served on them. Zam expressed the hope that the Trotskyists would try to win their objective by promoting discussion in the Party and not by launching any acrimonious campaign. ${ }^{2}$

But a campaign with no punches pulled was what the Trotskyists were soon to launch. Shachtman himself set the ball rolling with a long letter to the National Action Committee in which he condemned the NEC's resolution. “Military support to the People's Front Government - of Caballero, or Negrin, or even Azaña - to the extent that it really fights against the fascists: absolutely! Political support to a regime whose avowed goal is the preservation of capitalist democracy: absolutely not!" Since the Spanish resolution involved questions of basic importance it would have to be discussed thoroughly in every local and branch of the Party, Shachtman asserted. ${ }^{3}$

Thus even while the Clarity leaders were in the process of issuing

1 Minutes of the National Executive Committee Meeting, Philadelphia, 7-9 May 1937, Archives of the Socialist Party .

2 Joseph Carter to Cannon, 23 May 1937, Cannon Papers, Interview with Shachtman. James Burnham was a new recruit to Trotskyism. He broke with Trotsky and Cannon early in 1940 and gradually evolved into a self-styled "conservative". He is the author of The Managerial Revolution (194I) and several other works.

3 Shachtman to the National Action Committee, 20 May 1937, Cannon Papers. 
statements on how they intended to turn the Party into a disciplined, centralized organization, an intensive campaign for the repeal of the NEC's resolution was started in every branch by the Trotskyists. The Indiana State convention of the SP, controlled by the Trotskyists, adopted a resolution calling for a revision of the NEC resolution and for aid to the "revolutionary" organizations that were sought to be suppressed by the Loyalist government. In every branch and local Trotskyists moved resolutions expressing support to the position taken by the Indiana convention. If their motion was ruled out or voted down, they brought it up again in a variety of ways and, as a result, many meetings were thrown into turmoil as Trotskyists clashed with their opponents in bitter debate. ${ }^{1}$ The NEC and the Clarity leaders were stunned by the nature and tone of the Trotskyist attack. The Clarity leaders were further perturbed when they came to know of a "private" letter from James Burnham to Glen Trimble which was mimeographed and widely circulated among Party members by the Trotskyists. The letter purported to give an account of the NEC meeting and made it appear as though the Clarity group in the NEC was unable or unwilling to stand up to the "reactionary demands of the right wing". ${ }^{2}$ In California Jim Cannon publicly asserted that the Clarity group was lining up with the right wing and that only the strength of the revolutionary left wing could save the Party from betrayal. The policy of "changing the tone" was thus launched in right earnest.

\section{TROTSKY ADVISES SPLIT}

Jim Cannon loved a fight. And in no fight did he feel so much at home as in a fight involving "principles" as defined by himself. $\mathrm{He}$ had been chafing in his isolation in California; he could not overcome his sense of distaste in having had to conciliate such "fakers" as Thomas, Trager, and Tyler. The NEC's stand on Spain offered a chance for an uncompromising fight on "principles". Among his associates James Burnham was most skeptical about Cannon's line. He asserted that in many states the Trotskyist influence had not yet become firmly consolidated. By watchful waiting and by intensifying

1 They could not understand how the military struggle against fascism could be furthered if the socialist parties of all countries were to launch an attack on the Loyalist government as demanded by the Trotskyists. Nor could they see how an uprising against the government in the middle of a war could be justified, even if there was considerable provocation. See Socialist Call, III (29 May 1937), p. 4. Norman Thomas gave expression to similar views in a survey of the European situation written for the Party's official newspaper just before his departure from Europe. Ibid., III (I 2 June 1937), p. 3; (19 June 1937), p. 8. 2 Burnham to Trimble, I7 May 1937, Cannon Papers. 
their work, the Trotskyists could significantly improve their position, he argued. ${ }^{1}$ But it was Cannon who was interpreting Trotsky's thoughts correctly and it was Burnham who was out of step.

The oracle from Mexico City spoke out strongly and stridently in order to rally the waverers. Trotsky revealed his thoughts in a "strictly confidential" letter to Cannon and Burnham. He said that he was convinced that a turning point in history was nearing. His followers around the world would have to emerge under their own banner to meet the needs of the new situation. The next five months would witness four significant developments - the Spanish Civil war would "come to a dénouement"; the furious tempo of the Soviet persecutions would expose the Stalinist regime to "an incomparably greater extent" than ever before; the Blum experiment would end in bankruptcy and the people's front policy would receive a mortal blow; and, finally, the report of the Commission of Enquiry investigating Stalin's charges against Trotsky would be published "which must and will be annihilating for the Stalinist clique and for the Comintern bureaucracy." Trotsky continued:

The coincidence of all these factors promises to open an extremely favorable situation for our activity during the coming Fall. It would be criminal to meet this new situation as prisoners of Thomas, Trager, Tyler and Co. No, we must again appear on the scene as an independent party. It seems to me here that the anniversary of the October revolution is the deadline for the establishment of our complete political independence."2

Trotsky spelled out a programme of action to be followed by his American adherents. He said that they should mobilize their cadres for the new strategic line, namely, splitting the Socialist Party. To that end it was absolutely essential that they should establish their own weekly regardless of all "statutory considerations and diplomatic prudence". They should vigorously and relentlessly attack their opponents in the Socialist Party as "the agents of the Stalinist-reformist hangmen of the Russian revolution as well as the Spanish revolution... We cannot discuss with Altmanites and the Wisconsin people as with comrades. We must denounce them as traitors and rascals." By such a determined offensive hesitation among sympathizers and the "best elements of the Clarity faction" could be prevented.

The famed builder of the Red Army had even prepared battle plans by following which his American cohorts could break the

1 Burnham to Cannon, 22 May 1937, ibid.

2 "Wolfe" (Trotsky) to Burnham, Cannon, Glotzer and Weber, is June I937, ibid. 
Socialist Party and carry away with them its "best elements". Trotsky wrote:

"By July is [1937] all our comrades must be mobilized for the radical turn.

The first issue of our weekly must appear in the second half of July.

August and September: our campaign against the Right wing and, in the second place, against the Centrists.

Not later than November 7 we must appear as an independent party."1

\section{BURNHAM'S CRITICISM AND TROTSKY'S REJOINDER}

Cannon was enthusiastic about the master's analysis and recommendations, but Burnham sharply took issue with Trotsky. Could political questions be resolved according to a pre-determined time table, he asked. Should not the "intensity and tempo" of developments determine the pace at which the split from the Socialist Party should be carried out? Was Trotsky desirous of promoting sallies so that the American leadership, confronted with "irrevocable" facts, would find it impossible to draw back? Burnham clearly indicated by his line of questioning that precipitate action in the form of deliberate provocation and breach of discipline would not advance the Trotskyist objectives.

Trotsky replied to Burnham in a tone of thinly-veiled irritation. The line of the group, he said, must be determined by general political considerations and not by those of individual psychology. The intensity and tempo that Burnham appeared to favour were not sufficiently intensive and speedy to meet the demand of political developments. The line that he (Trotsky) had suggested called for "ideological delimitation and organizational separation". Should he have to teach his comrades even the minor details relating to techniques by which the line should be implemented? "It is an elementary rule of the game that we must throw responsibility for our emergency measures squarely upon the bureaucrats and their state of siege in the party. We must give to every step of our own the most comprehensible and convincing form. But the decisive steps must be taken in the next months, even at the risk that some sympathizers will remain in the S.P.", Trotsky emphasized. ${ }^{2}$

\section{ALTMAN MOVES AGAINST TROTSKYISTS}

The Clarity group was still so impressed with its own dominant position in the Party and the YPSL that it had little comprehension of

1 Ibid.

2 "Wolfe" (Trotsky) to Burnham, 25 June 1937, Cannon Papers. 
the plans that the Trotskyists were hatching. To Zam and Tyler the main threat to the Party came from the "right wing" led by Altman and, in a membership meeting in New York City on 26 May 1937, the Clarity group bitterly criticized Altman for "bureaucratic use" of the Party machinery. Altman retorted with equal warmth that he had absolutely no intention of permitting the Trotskyists to capture the Socialist Party. "From now on it is war", he declared. ${ }^{1}$ When a batch of applications from members of the YPSL of the Trotskyist group came up for scrutiny for admission as regular members of the SP, the City Executive Committee of Local New York (which had a majority of Altmanites) turned it down. There was immediately an outcry from the Trotskyists as well as from the Clarity group that Altman was starting a witch-hunt in the Party and was bent on using his bureaucratic authority to keep away all persons who would not bow down to his dictates. Leaders of the Clarity group were firmly of the opinion that every person who agreed to abide by the decision of the national convention of the Socialist Party had a right to remain in the Party and that no person should be subjected to disciplinary action because of the beliefs held by him. ${ }^{2}$

The Clarity leaders were also deeply suspicious of Altman's reported desire to bring about an electoral arrangement between the Socialist Party and the American Labor Party (ALP), a new political group that had been organized in New York City by former Old Guard Socialists, labour leaders and liberals. The ALP was organized in 1936 to win for Franklin D. Roosevelt liberal and labour voters who were unwilling to identify themselves with the Democratic Party's "machine" politics in New York state. Altman was of the view that by an accord with the ALP, the Socialists might make some gains in a forthcoming municipal campaign in New York City and also retain links with important trade unions in which Socialist influence had been fairly significant in the past. To the Clarity leaders such

1 A few days later a meeting organized by the New York Local to discuss the Spanish issue was marked by heckling and cat calls following which Altman adjourned it. Gus Tyler joined the Trotskyist, Maurice Spector, in criticizing Altman's action as illegal. Each side gave its version of the incident in mineographed "letters" to party members around the country. The incident proved that Altman was ready to use the worst bureaucratic subterfuges to split the Party, wrote Burnham. Altman's friends replied in a joint letter that the Trotskyists had entered the Party only to wreck it and that misguided Socialists of the Clarity group were giving aid and comfort to the disruptors. Burnham to "Dear Comrade", 7 June 1937; Spector to "Dear Comrade", 7 June 1937; Hal Siegel, Brendan Sexton and others to "Dear Comrade", June 1937, ibid.

2 The District Executive Committee of the New York YPSL in which the Clarity group was dominant adopted a resolution condemning Altman's action in strong language. Minutes of the District Executive Committee Meeting, New York YPSL, 18 June 1937, Archives of the Socialist Party. 
arguments sounded like rank heresy and shameful capitulationism. The Trotskyists too were totally opposed to any collaboration with the ALP.

It was when matters were in such a confusing stage that Norman Thomas returned to New York after his European trip. He was immediately swamped with a variety of complaints and counteraccusations by persons belonging to the various factions in the Party. Thomas had been following developments in the Party and he had become increasingly disturbed by the tone and nature of the line advocated by the Trotskyists. He could not subscribe to their stand on the Spanish question and could not understand why they should seek to make it the most basic issue in every branch and local of the Socialist Party of America. He realized at last that they looked at every problem "from the latitude and longitude of Mexico City or whatever might be the temporary home of the exiled Trotsky." Nevertheless he saw some force in the arguments of the Clarity leaders that members of the Trotskyist persuasion should not be punished for their beliefs. ${ }^{1}$ In short Thomas was gravely perplexed over the matter and did not have any ready-made solution to it.

A special session of the NEC was scheduled to be held in New York City on June 18 and 19. The Trotskyists were in no conciliatory mood. On the day before the opening of the NEC session, the Trotskyists organized a meeting at which they expounded their line on international developments and made no secret of their hostility towards the NEC. The principal speaker, Burnham, asserted that both the Socialist and Communist Internationals had miserably failed and that the establishment of the Fourth International had become an urgent necessity. This was the first time that the Trotskyists in the SP had openly raised the issue of the need for a Fourth International. Burnham also circulated at the meeting a mimeographed statement entitled "The Politics of Jack Altman" that called for a "reconstituted left wing" in the Party to fight against the "reactionaries".

Gus Tyler of the Clarity group was present at the meeting and he criticized the tactics adopted by the Trotskyists as indicative of a "split orientation". He said that his group favoured a truce in the Party and he urged the Trotskyists to lend support to that line. The Trotskyists, Tyler urged, should remain in the Party and, in collaboration with the Clarityites, should transform it into a revolutionary organisation. ${ }^{2}$ Several Trotskyists replied to Tyler's speech and harped

\footnotetext{
1 Thomas to Clarence Senior, I9 August 1937 , Thomas Papers. In weighing all the evidence Thomas found himself increasingly sympathetic to Altman's point of view, though he was opposed to mass expulsions.

2 Joe Carter to "Wolfe" (Trotsky), 22 June 1937, Cannon Papers.
} 
on the theme that the Clarity group always retreated before Altman. The developments in Spain had shown that a Fourth International was imperative to give the correct lead to the workers. If the Clarity group was seriously interested in bringing about left wing unity, it should join them in demanding the reversal of the NEC's stand on Spain.

\section{THE NEC ORDERS A TRUCE}

When the NEC convened on the following morning, Altman presented a detailed indictment of the 'Trotskyists and warned that the feeling among the majority of New York Socialists was so strong that they might resign en masse from the Party if the NEC failed to take vigorous action against the disrupters Raskin of Wisconsin and Lewis of Massachussetts joined Altman in condemning the Trotskyists. They emphasized that they did not advocate mass expulsions but favoured disciplinary action against leaders like Cannon, Shachtman, and Burnham. Thomas finally swung his weight on the side of the anti-Trotskyists. He argued that no one should be expelled from the Party merely because of former membership in the Workers Party or because he liked certain things that Trotsky advocated. But if the real allegiance of the person was not to the Socialist Party but to Trotsky or to a fourth international, he could hardly deserve a place in the SP.

The Clarity elements on the NEC were unmoved by Thomas's appeal and argued that mass expulsions of Trotskyists without concrete proof of disloyal behaviour, political explanation, or adequate preparation of Party members outside New York would lead to very adverse results. Repeatedly they emphasized that the loyalty of members should be tested not on the basis of beliefs but of actions. It was the duty of the NEC, they argued, to issue clear directives that would put an end to the fratricidal factional struggle and mobilize the membership for mass activity. ${ }^{1}$

The NEC finally adopted a resolution which represented to a considerable extent the Clarity point of view, with some concessions to Thomas and Raskin. The main idea behind the resolution was that there should be a period of truce in which all factional warfare would be banned and the directives of the NEC would be scrupulously

1 The account of the NEC meeting is drawn from the following sources: Lillian Symes to Jack Kahn and Travers Clement, 20 June 1937 , Goldberg-Weintraub Collection; Statement by Gus Tyler, Save the Socialist Party from the Wreckers!, June 1937, mimeographed, ibid.; Thomas to "Dear Comrades", 22 June r937; Thomas to members of the NEC, 2I July 1937; Thomas to the St. Louis Local of the SP, 27 July 1937, Thomas Papers. 
carried out. During the period of the truce, it was hoped, the situation in the Party would become clarified. To facilitate such a process the NEC called upon all members to "suspend organized attempts to apply pressure for changes of policy and for the initiation of new policy." The resolution stated that "affiliation with or allegiance to organizations of the Third International, committees for a 4 th or new international, or organizations or individuals outside of the Socialist Party aligned with such organizations without permission of the NEC is incompatible with membership in the Socialist Party..." In a move to counter the dissemination of factional literature by the Trotskyists or the Altmanites, the resolution decreed that no literature, other than that approved by the NEC, could be sold or distributed at open or closed meetings of the Party. The NEC also directed that membership meetings should be held in various places at which the decisions should be explained and warned that any campaign whatsoever against the decisions themselves would be impermissible. ${ }^{1}$

\section{TROTSKYIST BLUEPRINT FOR SPLIT}

The Trotskyists were in no mood to pay obeisance to the NEC or to Tyler, Zam, and others of their group. The clarion call had come from Trotsky and Cannon and Shachtman rapidly cleared the decks for action. In a confidential letter to all their comrades around the country, they spelled out the new line - the perspective, - as they were often fond of calling it. The perspective that all Trotskyists must keep before them was tersely summed up as "the inevitability of the split and the subordination of all our tactics to that idea." To ensure speedy and effective realization of that idea, the faction must revive its own weekly organ, regardless of the NEC's ban. The substance and emphasis of articles in the weekly should be of such a nature that very little would be left behind of the Socialist Party after the Trotskyists left it. They must discredit "politically and thoroughly, the Altman-Wisconsin wing as well as the Zam-Tyler wing and not... spare Thomas out of any pseudo-sentimental reasons." While maintaining "the most aggressive and irreconcilable attitude and intransigent stiffness on principle", Trotskyists should not quit the SP or withdraw from it. They should fight the social democrats at each step, "keep our op-

${ }^{1}$ Minutes of the National Executive Committee Meeting, New York, 19-20 June 1937, Archives of the Socialist Party. "NEC Decisions Direct Party to Mass Activity", in: Socialist Call, III (3 July I937), p. 5, (10 July 1937), p. 2. Lillian Symes, a senior member of the SP from California, wrote to Clarity colleagues in her state immediately after the meeting, that the NEC had proclaimed martial law in order to crack down on all splitters, right as well as left. The resolute action of the NEC had staved off the crisis and had preserved the Socialist Party, she added. 
ponents on the jump in every corner of the party, paralyzing the 'official' faction apparatus of our enemies, breaking down the S.P.organization-fetishism." Every legal means of struggle provided under the SP's constitution must be utilized and, as part of such a tactic, the NEC's Spanish resolution and its "gag rule" must be brought for a referendum of the membership. The resulting "political education" would bring many waverers to the Trotskyist side. The struggle must be taken into the YPSL and clear lines of division must be delineated so as to win maximum support from uncommitted elements among the youth.

The split must not under any circumstances be a "quiet" one, the Trotskyist leaders asserted. Its reverberations must be brought home to all revolutionary workers in and out of the Party. But it would be inadvisable to make it appear as though the opposition to the reformists was confined to Trotskyists in the Party. Wherever possible reliable "native" radicals should be advanced to formal leadership. In order to win support west of the Mississippi it was essential that California should be made to draw fire from the NEC; any action taken by the NEC against California would win sympathy and support from other state organisations in the West that were usually indifferent to factional struggles confined to New York. "Altman-Thomas-Zam and Co should simply be told to go to hell", declared Jim Cannon. ${ }^{1}$

Thus within a week after the NEC issued its directives, the Trotskyist generals had issued their battle instructions to their supporters. But even at this juncture Burnham expressed his misgivings and called for a reconsideration. Along with Maurice Spector and Joe Carter he demanded that Cannon and Shachtman should not give marching orders unless they received specific authorization from a plenum of the Action Committee of the Appeal Association. Why were Cannon and Shachtman placing the emphasis on speed rather than on effectiveness, they asked. Were they sure that the Trotskyist faction had made the maximum possible gains? Was it not true that there were many activists in the Socialist Party who were not yet fully ready to accept the implications of a split and of unity with the Trotskyists? From Chicago similar doubts were expressed by certain important members of the faction like Al Glotzer. ${ }^{2}$ Cannon was

${ }^{1}$ Cannon, Shachtman, and Trimble to "Dear Comrades", 29 June 1937 , Cannon Papers.

2 Burnham, Spector and Carter to "Dear Comrade", 7 July 1937; Carter to Shachtman, 8 July 1937, ibid. Interview with Glotzer. Shachtman told the writer in an interview that he too had been "petrified" when Trotsky advised his adherents to bring about a speedy culmination of the split. But he did not oppose Cannon's vigorous move to implement the line because he was afraid that such a course would split the Trotskyist group right down the middle. 
confident that his "line" would win the support of the majority of the Trotskyist faction and he hastened to summon a "plenum" as demanded by his critics. He was implementing Trotsky's line and he was not going to let Burnham or any other neophytes in revolutionary action stand in his way.

In any event the wheels had been set in motion and the first shot was fired at a meeting of the District Executive Committee of the New York City YPSL when a Trotskyist youth offered a motion condemning the NEC's directives relating to cessation of factional activity in the Party. The resolution was defeated but very soon it was evident that it was not an isolated move of a few hotheaded youngsters. In line with the strategy already agreed upon, Local San Francisco which was controlled by the Trotskyists passed an identical resolution and called upon "the entire party organization and membership to join with us in the defense of revolutionary socialism and its adherents." Glen Trimble, the leading "native" recruit of the Trotskyists in California, in a sizzling manifesto addressed to "All Revolutionary Socialists", called for united struggle against the "party wreckers" - a category in which he included the Altmanites, the Clarityites, and Norman Thomas. Revolutionaries in the Party had, therefore, no other alternative but to revive the Socialist Appeal as a medium for conveying their views on important issues, he asserted.2 The time table laid down by Trotsky and the strategy prescribed by Cannon were thus being faithfully implemented. As part of the "legal" struggle, Local San Francisco demanded a referendum on the NEC's resolution on the cessation of factional activities and the move was promptly supported by the requisite number of locals to make a referendum mandatory. ${ }^{3}$

1 Though ostensibly offered by a member of the YPSL, the resolution was apparently drafted by the Trotskyist leadership because it closely follows the analysis of Trotsky in his letter to Cannon and Shachtman. The resolution declared: "In the face of the worldshaking events of the Spanish revolution, the Soviet persecutions, the bankruptcy of the Blum regime, the threat of a new war, and the mighty upsurge of American labor, the NEC attempts to establish by decree the regime of a political prison, in order to muzzle the voice of the revolutionists at the bidding of the reactionary Right Wing, who defend the betrayers and assassins of the Spanish workers, the October revolution and the world labor movement." Minutes of the District Executive Committee Meeting, New York City YPSL, 25 June 1937, Archives of the Socialist Party. Also Florence De Long, secretary, Local San Francisco, to Roy Burt, executive secretary of the SP, 3 July 1937, Thomas Papers.

2 Trimble to "All Revolutionary Socialists," 8 July 1937, Thomas Papers.

3 A referendum of the entire membership was mandatory if at least five locals in three states having 20 per cent of the total membership of the Party, supported a motion to that effect. Locals in Rochester (New York), Akron (Ohio), St. Paul (Minnesota), and Fresno (California), supported the motion of Local San Francisco. 
ALTMAN WINS THOMAS' APPROVAL FOR ACTION AGAINST TROTSKYISTS

In the face of these developments Altman was unwilling to be hamstrung by the NEC resolution forbidding him to take action against the Trotskyists and he was supported in the main by Norman Thomas. Thomas urged Altman to work out a cautious procedure. On the basis of available evidence, charges could be drawn up in New York against Trotskyist leaders, he suggested. Stringent regulations could be drawn up for proper conduct of meetings, and infractions of the regulations could be made the basis for disciplinary action. The Socialist leader recommended these drastic measures because he became firmly convinced that the action of the Clarity group in trying to advance its factional ends by co-operating with the Trotskyists would mean the destruction of the Socialist Party. ${ }^{1}$

Altman proceeded to act on Thomas' advice and, at a meeting of the New York City Committee of the Party held on 6 July 1937, charges were levelled against certain leading Trotskyists, including James Burnham. Burnham was charged with having written and distributed a document, "The Politics of Jack Altman", which contained the "bitterest attack on the Party leadership, policies and principles ever published in recent years." Altman's motion for the expulsion of Burnham was passed by a vote of 43 to 24 , but it was short of the two-thirds majority needed for implementation. The Clarity representatives voted against the motion and opposed in vain another motion by Altman to suspend Burnham from the Party by one year. The new motion required only a simple majority to become effective and Altman commanded a comfortable margin of votes to make his motion prevail. ${ }^{2}$

In disciplined and competent manner the Trotskyists put into execution the next stage of their pre-determined plan. In every local Trotskyists, speaking in the name of the "left wing" introduced resolutions to express solidarity with the "revolutionary Socialists" who, they asserted, had been unconstitutionally suspended or expelled by the Altmanite clique. ${ }^{3} \mathrm{~A}$ new dimension was thus added to the "educational campaign" that they had already launched to win the support of as many members as possible while the Party crisis deepened.

Unfortunately it was exactly at this very time that the controversy over the idea of collaboration with the American Labor Party came to a head. Altman and Thomas were convinced that the SP could not

1 Memorandum by Thomas on: The Party Situation, June 1937, 'Thomas Papers.

2 Minutes of the Special Meeting of the City General Committee, Local New York, 6 July 1937, Archives of the Socialist Party. The Clarity representatives voted against taking disciplinary action against Butnham and two other Trotskyites.

3 Carter to "Dear Comrade", 7 July 1937, Cannon Papers. 
afford to isolate itself from the American Labor Party. Tyler, Zam and their Clarity colleagues regarded such talk as nothing short of liquidationism which they had always regarded as an even greater menace to the SP than Trotskyism. ${ }^{\mathrm{I}}$ It appeared to them that both on the right and on the left the Party was confronted with splitters. The forces of Clarity must put an end to this indiscipline and the writ of the NEC must be made to prevail. Gus Tyler came out with a flaming manifesto to Party members: SAVE THE SOCIALIST PARTY FROM THE WRECKERS! Criticizing both the Trotskyists and the Altmanites, Tyler asserted that the Socialist Party could only be saved if the members rallied behind the NEC and loyally supported its decisions. It was a struggle on two fronts that Tyler wanted: he would, however, train his heaviest guns against the Altmanites rather than the Trotskyists. ${ }^{2}$

The National Action Committee with the Clarity group in control decided to take speedy action to slap down Altman and prevent him from carrying out any more expulsions. It directed that all motions relating to "splitting and expulsionist tendencies in the party" should be made directly through the NEC. The NAC directed further that Local New York should not take any public action or issue any statements on the New York municipal campaign until the whole matter had been presented for consideration before the NEC. Swinging its guns then on the Trotskyists, the NAC declared that any attempt to revive the Socialist Appeal would be a direct violation of the decision of the National Convention and would call for disciplinary action. $^{3}$

Thomas regarded the action of the NAC in prohibiting expulsions by locals as completely misguided. He asserted that disciplinary action against certain Trotskyists had become absolutely inevitable in view of their disruptive tactics. Such action, even if it involved the loss of

1 Tyler, Zam, and their Clarity colleagues felt that Altman, with the support of Thomas, was definitely moving in the direction of collaboration with the ALP and of supporting Fiorello La Guardia for the mayoralty of New York. In the Socialist Call, editor Gus Tyler ran a series of articles "exposing" $\mathrm{La}$ Guardia's claim to be a friend of the working man. For the two opposing points of view see, Norman Thomas, "At the Front", in: Socialist Call, III (24 July 1937), p. 4; "Is La Guardia Friend of the Workers Or - New York Bankers?”, ed. (Io July 1937), p. 4.

2 Gus Tyler, Save the Socialist Party from the Wreckers!, op. cit. A mimeographed Clarity broadside addressed to "Comrades of the YPSL" pointed a sternly accusing finger at Altman for his "splitting role", "liquidationism", and "reformist orientation". "It is Altman who mobilized the campaign against the Trotskyists months prior to their split perspective, impelling them in that direction and provoking them into a counter offensive", it asserted. "The Die is Cast", mimeographed, July 1937, Goldberg-Weintraub Collection. 3 Minutes of the National Action Committee Meeting, Chicago, 30 July 1937, Archives of the Socialist Party. 
some members, was far better than "to have the Party become virtually Trotskyist under conditions which quite likely may compel us to resign or to face actual or virtual expulsion." Thomas asked his colleagues on the NEC how they could co-exist in the;same Party with the Trotskyist leaders who accused them of being the allies of the assassins of Barcelona. He warned that he was ready "to fight throughout the Party, if that should become necessary, this tendency... of exalting factionalism and factional issues at the expense of socialism in a critical time."1

Thus the Clarity group in the NEC, NAC, and in the Party press was firmly locked in combat with the anti-Trotskyists. With the municipal campaign warming up, the Altman group might well have persisted in its determination to collaborate with the ALP, thereby reaching a breaking point with Clarity or even with the Party. Had the Trotskyists withdrawn or toned down their own campaign against the NEC, the Clarity group might well have closed ranks with them to fight against the "liquidationists". But the Trotskyists did not give adequate consideration to these possibilities. They had chosen to defer to the judgment of Trotsky whose knowledge of political conditions in America was by no means very deep or profound. His time-table, however, was clear and specific: "The first issue of our weekly must appear in the second half of July." And his loyal associate, Jim Cannon, simply could not take his eyes off his "perspective": "the speediest culmination of the split."2

THE SOCIALIST PARTY EJECTS THE TROTSKYISTS

Trotskyist leaders from various parts of the country gathered in New York for the "Plenum" that Burnham had demanded. The Plenum, held on 24-25 July 1937 endorsed the Cannon-Shachtman line. The proceedings of the Plenum were secret but the fact of its being held could not be kept secret. Altman quickly seized the opportunity to frame charges against over fifty Trotskyists for having attended an anti-Party conclave and summoned a meeting of the City Central Committee to decide on the question of disciplinary action against them. The leaders of the Clarity group were even more enraged at the Altman move than over the open establishment of a dual apparatus by the Trotskyists. The NAC acted swiftly and appointed a committee to investigate the situation in New York

1 Thomas to Members of the NEC, 21 July 1937; Thomas to Senior, 19 July 1937; Thomas to St. Louis Local, 27 July 1937, Thomas Papers. Also Norman Thomas, "At the Front", in: Socialist Call, III (3 I July I937), p. 4.

2 Burnham, Shachtman and Trimble to "Dear Comrades", 29 June 1937, Cannon Papers. Interview with Shachtman. 
bearing on discipline. The committee was instructed to investigate both the alleged Plenum of the Trotskyists as well as the action of the Altman group against the Trotskyists. ${ }^{1}$ In New York, however, Altman was firmly determined to throw the Trotskyists out of the organization. He did not believe that the situation was one that would admit of delay and he felt that the NAC's idea of a committee of investigation was criminal folly in the face of a concerted effort by the Trotskyists to wreck the Socialist Party. ${ }^{2}$

On 9 August 1937 Altman convened the meeting of the Central Committee of the New York Local which promptly expelled 54 members of the Trotskyist group. ${ }^{3}$ The Clarity leaders were thrown into a frenzy by Altman's decisive action but were unable to determine what counter measures they should adopt to cut him down to size. Meanwhile Thomas moved swiftly to line up support for the action of the New York Central Committee among Party leaders in Wisconsin, Massachussets, and Connecticut. He wrote that the New York group was quite willing to co-operate with an investigating committee as proposed by the NEC, but in the face of a mounting Trotskyist threat and the absence of any specific plan from the NEC to meet it, the New York organization could no longer afford to postpone disciplinary action against subversive elements. To his trusted friend, Clarence Senior, the Socialist leader poured out his heart:

"I assure you that we want to go as far as we can in preserving all constitutional proprieties and protecting the authority of the NEC but we cannot allow that to extend to the virtual destruction of the Socialist Party in New York. In other words, if worse comes to worst, I think that almost all the present majority in New York, as individuals or collectively, would leave the Party, rather than accept the bureaucratic order of a factional majority in the NEC. To leave the Party or to break with the

1 Thomas to "Dear Comrades", 5 August 1937; Burt to the City Central Committee, New York, enclosing Minutes of the National Action Committee Meeting, 6 August 1937, Archives of the Socialist Party.

2 The position of the Altman group was expounded in a 13-page mimeographed "letter" from Aaron Levenstein to Clarence Senior, former national secretary of the SP. Levenstein asserted that the only enemy that his group recognized was the Trotskyist fifthcolumn in the Party. The Altmanites, he said, did not want a war against the Clarity group because they regarded the latter as fellow Socialists with differences only on minor issues. Levenstein to Senior, n.d., Goldberg-Weintraub Collection.

${ }^{3}$ Altman brushed aside the opposition of Robert Delson, a leader of the Clarity group, who sought to draw attention to the communication from the SP's executive secretary barting Party locals from initiating disciplinary action against members. Robert Delson, "Dear Comrade", August 1937, Archives of the Socialist Party. 
NEC would of course symbolize to the world the failure of my life's effort, at least insofar as any organization is concerned, but even that would be better than to live through many more months like those since my return. It would be impossible to stay in the kind of sect that would result in New York."1

The Clarity group thus confronted a determined stand by the Altman majority group in New York which had the support of the Party's most outstanding spokesman as well as that of the Wisconsin state organization. What kind of a Socialist Party would be left if they were to break with all of them? Could their dream of a revolutionary party be still salvaged by some kind of agreement with the rebellious Trotskyists? Any hopes that they might have harboured concerning the Trotskyists were dashed to the ground by the brazenly provocative acts that the latter unloosed in accordance with their plans. From Ward Rodgers, a Clarity stalwart in California, came an S.O.S.: the Trotskyists were on the point of taking over the California state organization. It could be frustrated only if the NEC suspended the charter of the state organization forthwith.

There was no Altmanite group in California and the lines of division were clearly between the Clarity group and the Trotskyists. The NEC which had demanded that Altman should not expel even a single member unless a detailed investigation had been undertaken by a special committee, was now compelled to suspend the charter of an entire state organization where the Clarity group was the object of attack by the Trotskyists. ${ }^{2}$

Before the NEC, and its Clarity members, could recover from their shock the Trotskyists initiated another act of open defiance - the revival of the Socialist Appeal, in violation of the NEC's directive. In its inaugural issue the journal carried a "Manifesto to the Members of the Socialist Party" expounding the Trotskyist version of the party controversies and denouncing Thomas and Altman as "La Guardia Socialists" who had raised a huge slush fund to split the Party and hand it over to the "ALP-La Guardia bureaucracy". When the NEC suspended the California charter, the Appeal denounced it

1 Thomas to "Dear Comrade", s August 1937, ibid.; Thomas to Senior, I9 August 1937 , Thomas Papers.

${ }^{2}$ In line with their tactic of using all constitutional devices to intensify the struggle within the Party, Trotskyists who controlled Local San Francisco demanded a referendum of the members of the state organization on the summoning of a state convention to discuss the NEC's directive relating to cessation of factional activity. The Clarity group in California, rightly fearing that the Trotskyist move was aimed at capturing the state organization, felt impelled to appeal to the NEC to suspend its character. See Ward Rodgers, Millie Goldberg and others, Vote 'No' on the Referendum for a Special Convention, mimeographed, August 1937, Goldberg-Weintraub Collection. 
as illegal and as proof of the "complete alliance between the AltmanThomas social-patriotic party liquidators and the 'Clarity' NEC majority."1

Jim Cannon had good reason to be satisfied with the barrage that the Appeal artillery had laid. From Coyoacan, Mexico, came a warm letter of congratulation. Trotsky wrote that he had read the first two issues of the Socialist Appeal with "great satisfaction". The material published was firm and militant, excellent in content and form. His only suggestion would be that the American comrades should pay greater attention to typography and proof-reading. ${ }^{2}$ The Old Bolshevik was a perfectionist and he wanted the split to be consummated in style.

With the scent of battle in their nostrils, the Trotskyist leaders stepped up their pressure. To show their contempt for the NEC they hawked the Socialist Appealpublicly as though they were challenging the NEC to take disciplinary action. In the YPSL circles the Trotskyist campaign mounted in intensity. Clarity had its strongest base in the YPSL and it suddenly became apparent to its youth representatives that the Trotskyists might, perhaps, "capture" the organization at the national convention scheduled to be held in September. ${ }^{3}$

The dilemma that the Clarity leaders faced had to be resolved one way or the other. At a tense meeting of the Clarity caucus held in New York, a member of the YPSL bluntly asked Gus Tyler who the real enemies of the SP were: the Altmanites or the Trotskyists. The question could no longer be avoided. Tyler replied that taking into account the course of the development of the Party, the answer would have to be: "the Trotskyists". At the same time he and Zam contended that the programme of expulsions initiated by Altman was a clear violation of Party discipline which should not be condoned. Irving Barshop, Secretary of the New York YPSL and a member of the Clarity caucus bitterly assailed their line and cried that they would be guilty of handing over the YPSL to the Trotskyists if they

1 "A Manifesto to Members of the Socialist Party", in: Socialist Appeal (New York), I (I4 August 1937), pp. 2-8; "Who is Financing the Right Wing Split Drive?", ibid., p. I; Glen Trimble, "NEC Suspends California Charter", ibid., (21 August 1937), pp. 1, 2; Left Wing Will Not Allow Itself to be Gagged by the Party Bureaucracy, ibid., (28 August 1937), pp. ro-II.

2 Trotsky to Cannon, 26 August 1937, Cannon Papers.

3 Irving Barshop, secretary of the New York YPSL, and an adherent of the Clarity group became convinced by this time that the youth organization was within an ace of being taken over by the Trotskyists. Independent members of the YPSL appealed to the Clarity leaders to take immediate steps to root out Trotskyism from the Party. An Appeal for the Preservation of the Young Socialist Movement, Io August 1937, mimeographed, Goldberg-Weintraub Collection. 
failed to endorse disciplinary action against the latter. Finally the caucus decided that all those connected with the publication or distribution of the Socialist Appeal should be brought up on charges before the YPSI Executive Committee and given a fair trial under democratic procedures. ${ }^{1}$

Thus, under pressure from their own youth leaders, Zam and Tyler finally had to agree to the same kind of procedure that they had condemned when followed by Altman. At a meeting of the District Executive Committee of the New York YPSL, a number of Trotskyist members of the YPSL were expelled on a charge of having participated in the distribution of the Appeal. Walking out of the meeting the Trotskyists proclaimed that they constituted the real YPSL of New York since they were really supported by the majority of the New York membership. ${ }^{2}$

The Socialist Party was thrown into chaos as a result of these developments. The National Executive Committee met in emergency session in New York on September 1937 and appointed a subcommittee to report on the activities of the "Appeal Association". The subcommittee reported that the Appeal Association was maintaining an apparatus indistinguishable from that of a separate party; that it had held a Plenum in which plans for a campaign against NEC decisions were finalized; and that in pursuance of the campaign a factional organ, the Socialist Appeal, had been launched. On the basis of these findings the NEC unanimously decided that all those connected with the Socialist Appeal would stand suspended with immediate effect. Those who repudiated their association with the Appeal could petition the NAC for reinstatement into the Socialist Party. Any person not reinstated by I October 1937 should be deemed to have been automatically expelled from the Party. ${ }^{3}$ The NEC's

1 Milt Cohen (New York) to Bill Kaufman (Cleveland), 17 August 1937, ibid.

${ }^{2}$ Ernest Erber, national chairman of the YPSL who had gone over to the Trotskyists, issued a statement accusing New York "centrists" of trying to oust left wingers in a bid to "steal" the forthcoming convention of the YPSL. Ernest Erber, "To All Circle Secretaries", in: Socialist Appeal, I (21 August 1 937), p. I. Al Hamilton, national secretary of the YPSL and an adherent of the Clarity group, issued a counter appeal to all members of the organization to repudiate Erber and his supporters. “... we are not going to have anything left in the League unless we act ruthlessly and immediately", Hamilton wrote to his friends in the Clarity group. Barshop to Hamilton, 20 August 1937; Hamilton to Barshop, 2I August 1937; Archives of the Socialist Party. Hamilton to Travers Clement, 2I August 1937, Goldberg-Weintraub Collection. The final showdown took place at the national convention of the YPSL held in Philadelphia at which Al Hamilton was able to muster a small majority to expel the Trotskyists.

${ }^{3}$ Roy Burt to All Branch and Local Secretaries, enclosing "Report of Sub-Committee on Question of Appeal Association, National Plenum of Appeal Association, Publication of 'Socialist Appeal' and Related Matters", 8 September 1937, Thomas Papers. "The Trotskyist Split”, ed., in: Socialist Call, III (r I September 1937), p. 4. 
resolution clearly amounted to an order of expulsion served on the Trotskyists.

Meanwhile in every local and branch of the Party the Trotskyists were busy presenting the developments in diverse ways, calculated to win to their side as many recruits as possible. They asserted that they were being thrown out of the Party because of their opposition to La Guardia, to the ALP, and to a people's front with the Communist Party. They were being thrown out because they were left wingers who advocated revolutionary socialism instead of capitulation to reformism; because they advocated a militant policy within the trade unions. And so on. Under their pre-arranged plan wherever they and their sympathizers were in a majority they passed resolutions expressing opposition to the NEC's reorganization proposals. In each case the branches and locals were promptly suspended by the NEC and the task of reorganization was entrusted to "loyal comrades".

To their consternation the Trotskyists found out that once war had been declared the despised social democrats could strike with a vigour that was in sharp contrast to their earlier lethargy and indecision. Trotsky's time-table envisaged a long-drawn out struggle including legal manoeuvres against the "Centrists" covering a period of two months - September and October 1937 - that would provide an opportunity for winning over a significant number of recruits. But the NEC's action provided no room for any legal manoeuvres and recognized no right of appeal or of referendum. The Trotskyists were unceremoniously thrown out of the Socialist Party.

Thus ended the adventure in American radical politics that Leon Trotsky had inspired, directed, and supervised.

A few days after the NEC of the Socialist Party had taken action against the Trotskyists, the Dewey Commission concluded its labours and announced its unanimous verdict:

“...We find that Prosecutor fantastically falsified Trotsky's role before, during and after the October Revolution.

We therefore find the Moscow trials to be frame-ups.

We therefore find Trotsky and [his son] Sedov not guilty."1

Trotsky had achieved his objective. He was not one to give way to "sickly sentimentalism" and to brood over the means adopted to attain his goal.

\section{CONCLUDING OBSERVATIONS}

Within a few weeks after the NEC meeting the Trotskyists were 1 "Summary of Findings," appended in: Trotsky, Stalin's Frame-Up System, op. cit., pp. I 29-3I. 
expelled from all branches and locals of the Socialist Party and from the YPSL. In addition to that of California, the NEC had to suspend the charters of the state organizations in Indiana, Minnesota, and Ohio where the Trotskyists were strongly entrenched. Some locals in other states where a similar situation prevailed were "reorganized" by the elimination of Trotskyist office bearers and members. The Trotskyists were able to take with them a significant segment of the Young People's Socialist League but only a small number of adult members of the Party. None of the documents put out by the Trotskyists or the Socialist Party subsequently gives an indication of the number of persons whom the Trotskyists were able to take away from the SP.1 Apparently it was well below a thousand.

Jim Cannon himself, in a reference to the subject in 1940, said that the Trotskyists were able to win "a few hundred people". This was certainly much less than what he had hoped to gain when he originally laid plans for entering the Socialist Party. It was certainly much less than what the Trotskyists might have succeeded in gaining had they followed the cautious approach advocated by Burnham instead of the all-out splitting tactics that Cannon initiated under the guidence of Trotsky. In any event at least as far as Cannon was concerned it was not the number of captives that was of the greatest significance. Of crucial importance to him was the success of the Committee for the Defense of Leon Trotsky which, in his opinion, was facilitated by the fact that the Trotskyists were inside the Socialist Party. Trotsky himself was convinced of the great value of the manoeuvre by which "the best natives" in America were won over to defending his cause against Stalin's massive onslaught. ${ }^{2}$ But it is legitimate to pose the query whether "the best natives" of America - persons like John Dewey and Norman Thomas - would have adopted a different attitude towards Trotsky's tribulations even if the manoeuvre had not been implemented at all. Generally speaking Trotsky regarded such men as political imbeciles or charlatans. The basic decency and fairness of the truly civilized and humane individual were to him apparently foibles to be exploited when necessary by the tacticians of revolution.

Trotsky and Cannon believed, moreover, that by their destructive foray into the Socialist Party they had greatly advanced the cause of revolution in the United States. The most important result of their fight in the SP, Cannon boasted subsequently, was that "in the process of winning over and partly educating a few hundred new

${ }^{1}$ Shachtman told the writer in an interview that the number of "captives" that the Trotskyists were able to take from the SP was not over three hundred.

2 Trotsky to Glotzer, r 8 September 1937, Cannon Papers; Cannon, History,op. cit., p. 241. 
people we also demolished the opportunist party of Thomas and Co."1 When Cannon had a personal meeting with Trotsky soon after his exit from the SP he described to the latter the pitiful state in which the Socialist Party had been left as a result of the factional struggle. Trotsky responded that such a result alone would have justified entrance into the SP, even if the Trotskyists had not been able to win a single convert. The demoralization of the SP, Cannon modestly acknowledged, was "a great achievement, because it [the SP] was an obstacle in the path of building a revolutionary party."2

That the Socialist Party was hit hard by the Trotskyist incursion was undeniable. More serious than the loss of a few hundred members was the utter futility of wasting months of inner-party conflict at a time when the Party should have thrown itself with the maximum possible energy into the militant upsurge of labour that the Congress of Industrial Organizations was spearheading. But the energies of the Socialists were sapped by the internal struggle in which they were quicker to suspect one another of such diseases as reformism or sectarianism than to fight against a common enemy; in which they were more prone to discuss the Russian trials or the role of the POUM than to agree upon a concerted programme of work.

Of course American Socialism could not isolate itself from the issues posed by such significant events as the Russian trials and the Spanish civil war. But an obsessive concern with external issues to the neglect of urgent tasks at hand enfeebled the Party and enabled the Trotskyists to accentuate the differences among the Socialists for their own purposes. ${ }^{3}$ The case of the Socialist Party of America provides yet another illustration of the problems confronted by an open, democratic party in dealing with the machinations of a disciplined group that succeeds in infiltrating it and subsequently using it for its own aims. While the Socialist Party was in the throes of this predicament, the Communist Party, implementing its own "Popular Front" tactic, began to make headway as a more significant factor than the Socialist Party on the American political scene.

What then of Trotsky's own role in this episode? Viewed as a deliberate, cold-blooded manoeuvre to bring into existence an international inquiry commission for the investigation of Stalin's charges, Trotsky's incursion into American radical politics during the period under review could be counted as a success. The question

\footnotetext{
1 James P. Cannon, Struggle for a Proletarian Party (New York, I943), p. I 44.

2 Cannon, History, op. cit., pp. 25 I-4.

3 Norman Thomas told the writer in an interview that the decision to admit the Trotskyists in the SP without thorough and adequate consideration was one of the most serious political mistakes that he had ever made.
} 
may be asked whether Trotsky was, consciously or not, so egoistic and self-centred that he did not hesitate to visit various vicissitudes on his American followers in his personal pursuit of vindication against Stalin's accusations. When the question was posed to Jim Cannon, who still is Trotsky's principal apostle in the United States, and to Max Shachtman, who no longer worships at the Trotskyist shrine, the reaction was one of pained protest. Both declared with passionate vehemence that Trotsky was "completely selfless" and that he never, at any time, put personal considerations ahead of the cause of world revolution. ${ }^{1}$ If the Bolshevik's intervention in American radical politics during $1935-37$ is to be judged as an exercise in promoting proletarian revolution in a capitalist nation, the verdict will have to be far from flattering.

It could well be that to Trotsky the fight for self-vindication was the best possible service that he could render to the cause of the international "opposition" to the Stalinist line. He was convinced that Stalin was determined to stamp out the opposition by discrediting and, if possible, destroying Trotsky. Aware of his position as the outstanding international leader of that opposition and feverishly anxious to weld his weak and scattered band of followers into a Fourth International, Trotsky probably regarded it as a solemn duty to defend himself - in order to save the cause. It is possible that his course was not dictated by considerations of personal "selfishness" or "selflessness". To him it was a matter of political faith. And, in practice, Bolshevik political faith is seen to involve a high estimation of the role and importance of the leader.

The episode that has been described does not bring forth a picture of Trotsky as a gifted or far-sighted organizer of political action. Perhaps it throws some light on why this volatile and opinionated polemicist proved no match for the patient, shrewd, determined, and ruthless organizationman from Georgia, Josef Stalin. ${ }^{2}$

1 Interviews with Cannon and Shachtman.

2 The present writer is grateful to his dear friend, Mr. Frits Kool, for many valuable comments and criticisms relating to this article. 